\title{
Treatment of HMX and RDX Contamination
}

Robert E. Card, Jr.

Texas A\&M University

College Station, Texas
Robin Autenrieth

Texas A\&M University

College Station, Texas

Submitted for publication to

Amarillo National Resource Center for Plutonium

March 1998

MASTER

DISTRIBUTION OF THIS DOCUMENT IS UNLMITED 


\section{DISCLAIMER}

This report was prepared as an account of work sponsored by an agency of the United States Government. Neither the United States Governmeat nor any agency thereof, nor any of their employees, makes any warranty, express or implied, or assumes any legal liability or responsibility for the accuracy, completeness, or usefulness of any information, apparatus, product, or process disclosed, or represents that its use would not infringe privately owned rights. Reference herein to any specilic commercial product, process, or service by trade name, trademark, manufacturer, or otherwise does not necessarily constitute or imply its endorsement, recommendation, or favoring by the United States Government or any agency thereof. The views and opinions of authors expressed herein do not necessarily state or reflect those of the United States Government or any agency thereof. 


\section{DISCLAIMER}

Portions of this document may be illegible electronic image products. Images are produced from the best available original document. 


\author{
Abstract \\ Treatment of HMX and RDX Contamination \\ Robert E. Card, Jr. and Robin L. Autenrieth \\ Texas A\&M University, College Station, Texas
}

HMX and RDX are often found in the soil, groundwater, and surface waters at facilities where they are manufactured as the result of negligent disposal methods. The toxicity of these compounds and their degradation products has led to concern about their fate in the environment and the potential for human exposure. HMX and RDX are recalcitrant in the environment, with low rates of biodegradation and photolysis.

Several methods of treating contaminated soils and waters have been developed and studied. Many of these technologies (i.e., carbon adsorption, oxidation, and chemical treatment) have been developed to treat munition plant wastewaters that are contaminated with explosives. These methods need to be adapted to remediate contaminated water. Other technologies such as bioremediation and composting are being developed as methods of remediating HMX and RDX contamination in a solid matrix. This report describes and evaluates each of these technologies.

This report also describes the processes which affect HMX and RDX in the environment. The major transformation processes of RDX and HMX in the environment are biodegradation and photolysis. A major factor affecting the transport and treatment of RDX and HMX in soil-water environments is their sorption and desorption to soil particles. Finally, this report draws conclusions as to which treatment methods are currently most suitable for the remediation of contaminated soils and waters. 


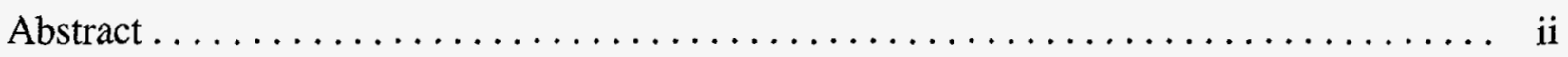

Table of Contents $\ldots \ldots \ldots \ldots \ldots \ldots \ldots \ldots \ldots \ldots \ldots \ldots \ldots \ldots \ldots \ldots \ldots \ldots \ldots \ldots \ldots$ iii

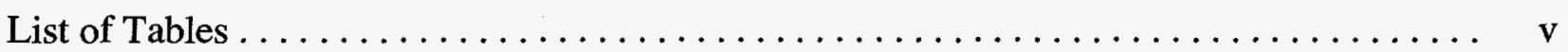

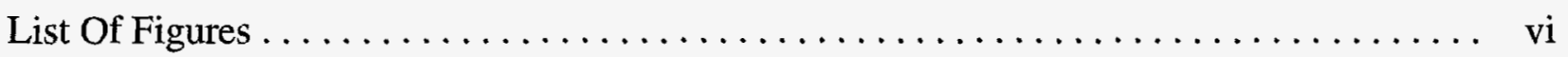

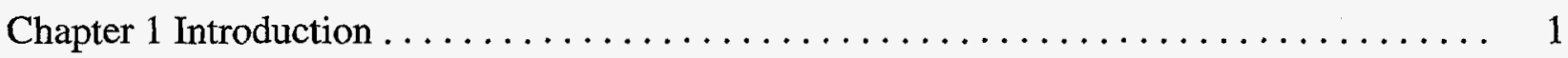

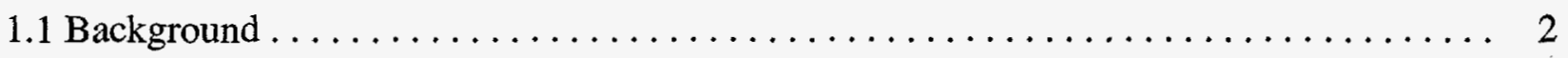

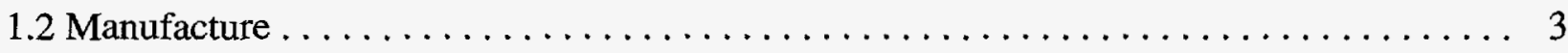

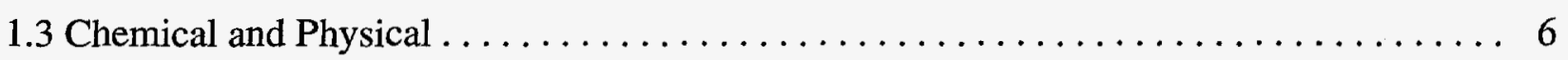

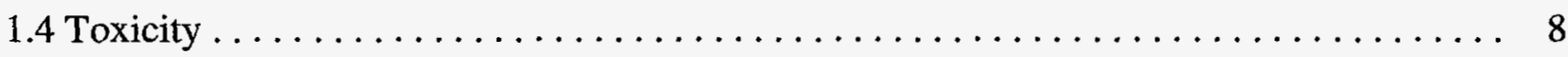

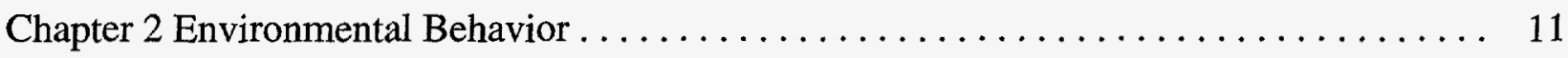

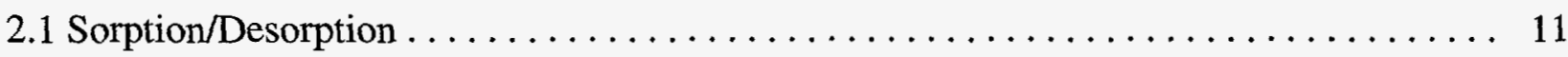

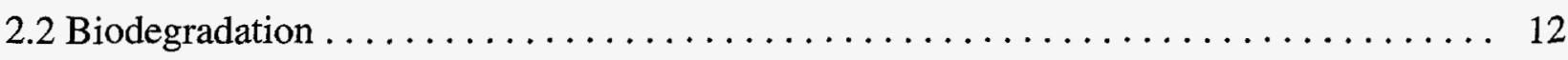

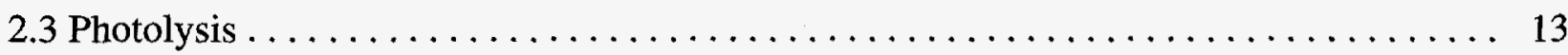

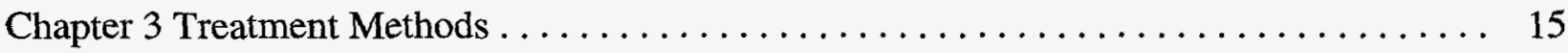

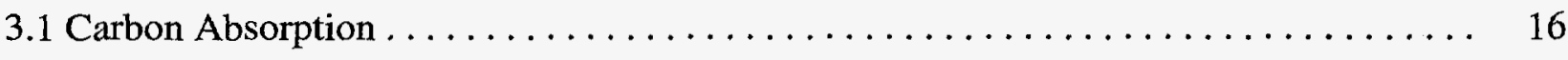

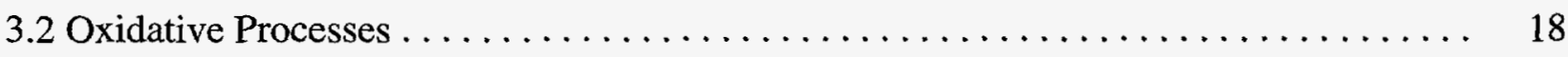

3.3 Biodegradation $\ldots \ldots \ldots \ldots \ldots \ldots \ldots \ldots \ldots \ldots \ldots \ldots \ldots \ldots \ldots \ldots \ldots \ldots \ldots \ldots \ldots \ldots, 23$ 
Table of Contents

Page

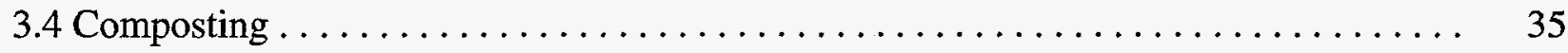

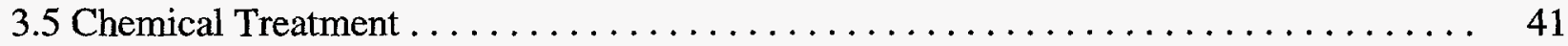

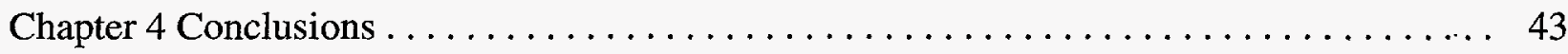

References............................................ 45 


\section{List of Tables}

Table

Page

1.1 Pounds of reactants for a $100 \mathrm{lb}$. batch $\ldots \ldots \ldots \ldots \ldots \ldots \ldots \ldots$

1.2 Chemical and physical properties of $\mathrm{HMX}$ and $\mathrm{RDX} \ldots \ldots \ldots \ldots \ldots \ldots$

1.3 Health advisory standards for $\mathrm{HMX}$ and $\mathrm{RDX} \ldots \ldots \ldots \ldots \ldots \ldots$

1.4 Comparison of the toxicity and carcinogenicity values of $\mathrm{RDX}, \mathrm{HMX}$, and their degradation products $\ldots \ldots \ldots \ldots \ldots \ldots \ldots$

2.1 Photolytic degradation rates for HMX and RDX in Holston River water ........ 14

3.1 Photolysis of RDX in a laminar flow tray $\ldots \ldots \ldots \ldots \ldots \ldots \ldots \ldots$

3.2 Mixed zero and first order rate parameters for RDX and HMX decomposition . . . . 20

$3.3 \mathrm{UV}-\mathrm{H}_{2} \mathrm{O}_{2}$ treatment first-order degradation rates for $\mathrm{RDX}$ and $\mathrm{HMX} \ldots \ldots \ldots \ldots 21$

3.4 Initial concentrations and first-order rate constants of HMX and RDX in corona oxidation study $\ldots \ldots \ldots \ldots \ldots \ldots$

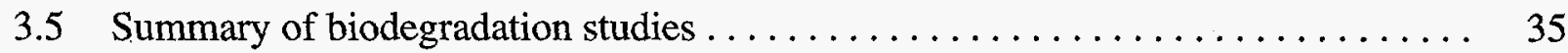




\section{List of Figures}

Figure

Page

1.1 Flow diagram of the RDX and HMX manufacturing process at Holston AAP ...... 5

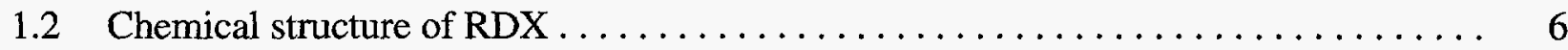

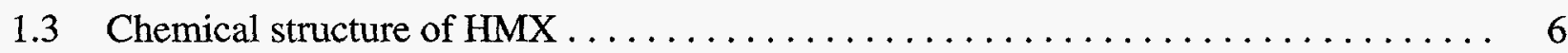

3.1 Proposed pathway for the anaerobic degradation of $\mathrm{RDX} \ldots \ldots \ldots \ldots \ldots \ldots \ldots 26$

3.2 Proposed pathway for the formation of mono- and dinitroso derivatives of HMX $\ldots .27$

3.3 Block flow diagram of proposed bioreactor/activated

carbon system for the treatment of pink water $\ldots \ldots \ldots \ldots \ldots \ldots \ldots \ldots \ldots \ldots, 31$

3.4 Methylene-N-(hydroxymethyl)-hydroxylamine-N'-(hydroxymethyl)nitroamine . . . . . 34 


\section{Chapter 1 Introduction}

The manufacture and use of HMX and RDX in the United States has led to the contamination of soil and water at a large number government installations. The toxicity and potential carcinogenicity of these compounds has led to concern about their fate in the environment and the potential for human exposure.

The recalcitrance and toxicity of RDX makes the remediation and monitoring of contaminated sites a necessity. The two major transformation processes of HMX and RDX in the environment, biodegradation and photolysis, occur at very slow rates, making these chemicals persistent in the environment. Many of the degradation products are more toxic than HMX and RDX making it undesirable to allow them to decompose in soils and water.

A variety of methods have been developed for the treatment of waters contaminated with HMX and RDX including: carbon adsorption, oxidation, biodegradation, composting, and chemical treatment. Many of these technologies were developed to treat explosivescontaminated waters generated from munitions manufacture and handling, and have not yet been adapted to the remediation of contaminated waters. This paper describes and evaluates each of these remediation technologies. 


\subsection{Background}

The use of HMX and RDX as explosives became common during World War II when their use became widespread due to their relative stability, which is only slightly less than TNT; and their explosive power, much greater than TNT. Since then, HMX and RDX have been used in detonators, primers, mines, rocket boosters, and plastic explosives (Yinon. 1990).

During their early manufacture, wastewaters generated at the munitions plant were often dumped into unlined pits. While this practice has ended, it had already led to the contamination of soil, surface water, and groundwater at approximately 28 sites in the United States (Griest, et al. 1990). The following is a list of all the sites that are potentially contaminated with RDX and/or HMX, identified during the course of this study.

Cornhusker AAP - Grand Island, Nebraska

Iowa AAP - Middletown, Iowa

Joilet AAP - Joilet, Ilinois

Kansas AAP - Parsons, Kansas

Lonestar AAP - Texarkana, Texas

Milan AAP - Milan Tennessee

Louisiana AAP - Shreveport, Louisiana

Holston AAP - Kingsport, Tennessee

US Navy - Crane, Indiana

US Navy - Hawthorne, Nevada

US Navy - McAlster, Oklahoma

US Navy - Yorktown, Virginia

US Army - Umatilla, Oregon

Pantex Plant - Amarillo, Texas

Los Alamos National Laboratory

Bangor Naval Submarine Base - Bangor, Washington

Savanna Army Depot - Savanna, Illinois

(Doyle and Kitchens. 1993; Kitts, et al. 1994; Sullivan, et al. 1979; US 1991, 1992)

Now that the US is disassembling many of its nuclear weapons, the explosives in the detonation devices needs to be destroyed. 


\subsection{Manufacture}

The most common methods of manufacturing RDX are the Woolwich and Bachmann processes. In the Woolwich process hexamine $\left(\mathrm{C}_{6} \mathrm{H}_{12} \mathrm{~N}_{4}\right)$ is nitrated directly as shown in Equation 1.1.

$$
\mathrm{C}_{6} \mathrm{H}_{12} \mathrm{~N}_{4}+4 \mathrm{HNO}_{3} \rightarrow \mathrm{RDX}+3 \mathrm{CO}_{2}+2 \mathrm{~N}_{2}+6 \mathrm{H}_{2} \mathrm{O}
$$

In the Bachmann process, hexamine is nitrated indirectly by an ammonium nitrate/nitric acid mixture in the presence of acetic acid and acetic anhydride at $75^{\circ} \mathrm{C}$, as summarized in Equation 1.2.

$$
\mathrm{C}_{6} \mathrm{H}_{12} \mathrm{~N}_{4}+4 \mathrm{HNO}_{3}+2 \mathrm{NH}_{4} \mathrm{NO}_{3}+6\left(\mathrm{CH}_{3} \mathrm{CO}\right)_{2} \mathrm{O} \rightarrow 2 \mathrm{RDX}+12 \mathrm{CH}_{3} \mathrm{COOH}
$$

The product from this reaction contains approximately $79 \% \mathrm{RDX}, 6 \% \mathrm{HMX}$, and $15 \%$ intermediates. The Bachmann process has proven to be more adaptable to large-scale production than direct nitration. HMX is manufactured through a modified Bachmann process in which HMX is the main product and RDX is a by-product (Yinon. 1990).

The following is a description of the production of HMX and RDX by the Bachmann process at the Holston Army Ammunition Plant (AAP) as explained in Kitchens, et al (1978). The manufacturing process and starting chemicals used in the production of HMX and RDX are the same; only the proportions of the materials are different, as shown in Table 1.1.

In preparation for the reaction, hexamine is dissolved in glacial acetic acid. The hexamine/acetic acid solution is pumped into the reactor with nitric acid/ammonium nitrate, acetic acid, and acetic anhydride. The resulting reaction slurry is transferred to an aging tank 
where the intermediates are further reacted to produce RDX and HMX. The slurry is then pumped to the simmering tank where it is cooled to $50^{\circ} \mathrm{C}$ and the acetic acid is diluted to $65 \%$.

Table 1.1: Pounds of Reactants for a $100 \mathrm{lb}$. Batch (Kitchens, et al. 1978).

\begin{tabular}{|l|c|c|}
\hline \multicolumn{1}{|c|}{ Reactants } & $\begin{array}{c}\text { Lbs. for RDX } \\
\text { Production }\end{array}$ & $\begin{array}{c}\text { Lbs. for HMX } \\
\text { Production }\end{array}$ \\
\hline Ammonium Nitrate & 17.2 & $\{11.0\}$ \\
\hline 98\% Nitric Acid & 13.6 & \\
\hline Hexamine & 9.2 & 17.0 \\
\hline Acetic Acid & 15.0 & 18.0 \\
\hline Acetic Anhydride & 45.0 & 54.0 \\
\hline
\end{tabular}

The acid in the final reaction slurry is removed by a vacuum system; afterwards the explosives are washed with filtered water. The resulting dilute acid water is removed by the vacuum system and the washed explosives are slurried with filtered water.

The explosives are then recrystallized in a using solvent, usually cyclohexanol for RDX and acetone for HMX. The solvent is then distilled off, and the recrystallized explosives slurry is pumped into receiving carts, where vacuum probes are inserted into the mixture to remove all the water.

The explosives are then ground and mixed with other materials, such as TNT and wax, in a heated kettle. The heated explosives are poured onto a belt where it cools and solidifies (Kitchens, et al. 1978). A flow diagram of the process is shown in Figure 1.1. 


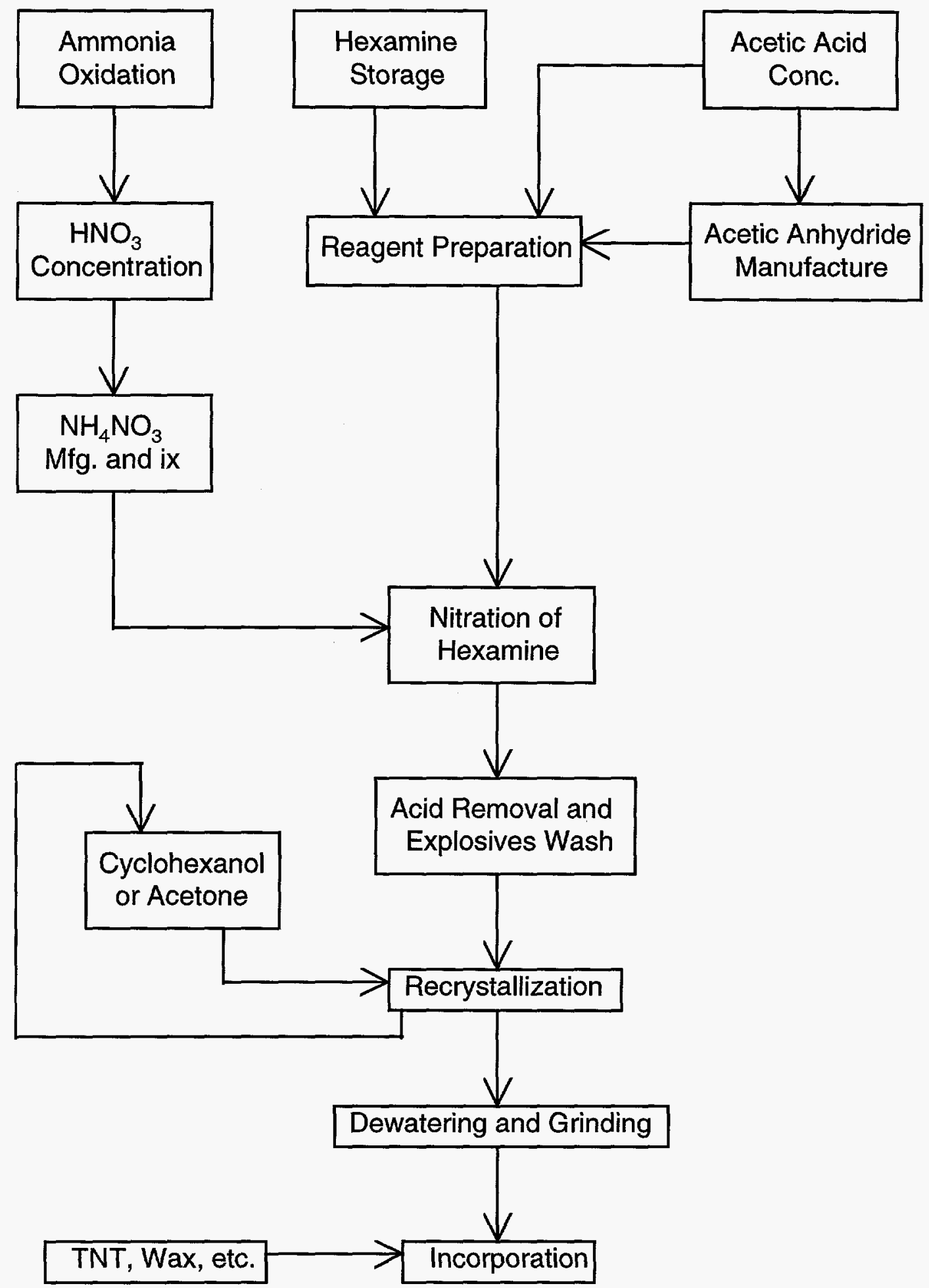

Figure 1.1: Flow Diagram of RDX and HMX Manufacturing Process at Holston AAP (Kitchens, et al. 1978) 


\subsection{Physical and Chemical Properties}

RDX (Figure 1.2) is a colorless polycrystalline high-explosive that was developed for use during World War II. RDX is short for Research Department eXplosive or Royal Demolition eXplosive. It is also known as cyclonite, cyclotrimethylenetrinitramine, hexogen, and hexahydro1,3,5-trinitro-1,3,5-triazine (Gibbs and Popolato. 1980). Physical and chemical properties of RDX are presented in Table 1.1.

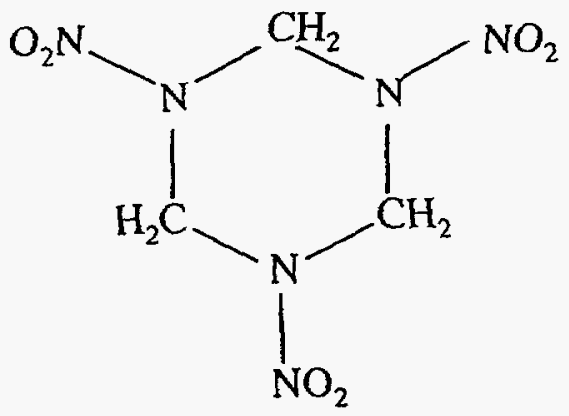

Figure 1.2: Chemical Structure of RDX.

HMX (Figure 1.3) is a colorless polycrystalline high explosive similar to RDX. HMX has a higher melting point than RDX and was thus named HMX for High Melting eXplosive. It is also known as octogen, octahydro-1,3,5,7,-tetranitro-1,3,5,7-tetrazocine, and cyclotetramethylene-tetranitramine (Gibbs and Popolato. 1980).<smiles>[2H]C1N([N+](=O)[O-])C(C)N([N+](=O)[O-])C(=O)N([N+](=O)[O-])N1[N+](=O)[O-]</smiles>

Figure 1.3: Chemical Structure of HMX. 
HMX exists in four polymorphic forms, $\alpha, \beta, \gamma$, and $\delta$. The $\alpha, \beta$, and $\gamma$, are all stable at room temperature, while the $\delta$ readily transforms. The $\beta$ form of HMX is most desirable because it is the least sensitive and most stable to impact (Yinon and Zitrin. 1993). Physical and chemical properties for the $\beta$ form of HMX are given in Table 1.2.

Table 1.2: Chemical and Physical Properties of HMX and RDX (Rosenblatt, et al. 1991).

\begin{tabular}{|l|c|c|}
\cline { 2 - 3 } \multicolumn{1}{c|}{} & RDX & HMX \\
\hline CAS Number & $121-82-4$ & $2691-41-0$ \\
\hline Empirical Formula & $\mathrm{C}_{3} \mathrm{H}_{6} \mathrm{~N}_{6} \mathrm{O}_{6}$ & $\mathrm{C}_{4} \mathrm{H}_{8} \mathrm{~N}_{8} \mathrm{O}_{8}$ \\
\hline Molecular Weight & 222.15 & 296.20 \\
\hline Melting Point $\left({ }^{\circ} \mathrm{C}\right)$ & 205 & 286 \\
\hline Density $\left(\mathrm{g} / \mathrm{cm}^{3}\right)$ & 1.83 & 1.90 \\
\hline $\begin{array}{l}\text { Water Solubility } \\
\left.\text { (mg/ } 25^{\circ} \mathrm{C}\right)\end{array}$ & 60 & 5 \\
\hline $\begin{array}{l}\text { Vapor Pressure } \\
\left.\text { (torr, } 25^{\circ} \mathrm{C}\right)\end{array}$ & $4.03 \times 10^{-9}$ & $3.33 \times 10^{-14}$ \\
\hline $\begin{array}{l}\mathrm{K}_{\mathrm{H}} \\
\left.\text { (atm- } \mathrm{m}^{3} / \mathrm{mole}, 25^{\circ} \mathrm{C}\right)\end{array}$ & $1.96 \times 10^{-11}$ & $2.60 \times 10^{-15}$ \\
\hline Log $\mathrm{K}_{\mathrm{ow}}$ & $0.87,0.81,0.86$ & $0.26,0.06$ \\
\hline $\mathrm{Log} \mathrm{K}_{\mathrm{oc}}$ & 2.00 & 0.54 \\
\hline
\end{tabular}

As an explosive, HMX is superior to RDX. Because of its higher density, HMX is used where high energy and lower volume are important. HMX is more resistant to degradation and chemical substitution than RDX (Urbanski. 1963). HMX is used in binary explosives, solid-fuel rocket propellants, as a burster charge for artillery shells, and to implode fissionable material in nuclear devices (Gibbs and Popolato. 1980; Yinon. 1990).

HMX and RDX can be analyzed by several methods. High-pressure liquid chromatography (HPLC) has been widely used to separate munitions mixtures. Coupled with a mass spectrometer, an HPLC can be used to analyze HMX and RDX in low nanogram to 
picogram quantities. RDX and HMX have been well characterized by gas chromatography (Rosenblatt, et al. 1991).

\subsection{Toxicity}

One of the primary objectives of hazardous waste remediation is to reduce or eliminate the threat to human health and the environment. The toxicity of the contaminants is often used to quantify the threat. To the impact of treatment methods, the toxicity of the parent chemicals and the degradation products must be compared.

The data available on the effects of RDX poisoning on humans results from inhalation studies on munitions plant workers. The effects of RDX poisoning usually develop within half an hour to several hours after exposure. Symptoms include confusion, dizziness, convulsions, loss of consciousness, vomiting, headaches, and nausea. Full recovery may require several days to two months. The majority of RDX poisoning cases were munitions plants workers exposed during World War II (Yinon. 1990).

When orally administered in rats and mice RDX is completely absorbed and rapidly distributed. The highest concentrations of RDX are found in the kidneys, followed by the liver, brain, and heart. Long-term effects of RDX exposure in rats and mice are increased liver weight and testicular degeneration (McLellan, et al. 1988a).

No toxic effects have been observed in munitions plant workers potentially exposed to HMX. In feeding studies conducted on rats and mice, toxic effects included hyperkinesia, anataxia, and convulsions. Unlike RDX, when orally administered the majority of HMX is excreted in the feces (70\% in mice, $85 \%$ in rats). It is postulated that the poor absorption of HMX is due to its low water solubility (McLellan, et al. 1988b). 
Health advisory standards for RDX and HMX have been developed by the Environmental Protection Agency, Office of Drinking Water. Health advisories are the concentrations of drinking water contaminants at which adverse health effects are not expected to occur over the duration of the exposure. These standards are not legally enforceable and are subject to change as new data becomes available. Longer-term standards are based on an exposure duration of approximately 7 years, or 10\% of an individual's lifetime RDX (McLellan, et al. 1988a, 1988b). Health advisory standards for RDX and HMX are given in Table 1.3.

Table 1.3: Health Advisory Standards for HMX and RDX (McLellan, et al. 1988a, 1988b).

\begin{tabular}{|c|c|c|}
\hline \multirow{2}{*}{ Exposure Duration } & \multicolumn{2}{|c|}{ Exposure Concentration $(\mathrm{mg} / \mathrm{L})$} \\
\cline { 2 - 3 } & RDX & HMX \\
\hline One day & 0.1 & 5 \\
Ten Day & 0.1 & 5 \\
Longer-term child & 0.1 & 5 \\
Longer-term adult & 0.35 & 20 \\
Lifetime & 0.002 & 0.4 \\
\hline
\end{tabular}

The primary route of exposure of RDX and HMX released to the environment is the ingestion of contaminated surface and groundwaters that have migrated offsite. The toxicity of HMX and RDX through the ingestion of contaminated water is limited by their low solubilities. Due to the restricted access to sites where RDX and HMX contamination has occurred, exposure to contaminated soil is not likely. However, because of the high concentrations, over 10,000 ppm at some locations, the inhalation and ingestion of airborne particulates is a concern for workers.

Some RDX degradation products are known carcinogens or mutagens. 1,2dimethylhydrazine, an anaerobic degradation product of RDX, has been identified as a cancer- 
causing agent in rats (Fiala. 1977). Other RDX degradation products of concern include: RDX nitroso derivatives, 1,1-dimethylhydrazine, hydrazine, formaldehyde, and methanol (McCormick et al. 1981). Nitrate, nitrite, formaldehyde, and 1,1-dimethylhydrazine have been identified as HMX degradation products (Spanggord, et al. 1983a).

A comparison of the toxicity of RDX and HMX with some of their degradation products is shown in Table 1.4. $\mathrm{LD}_{50}$ is the dose of a chemical which causes the death of $50 \%$ of the animals in the experiment.

Table 1.4: Comparison of the toxicity and carcinogenicity values of RDX, HMX, and their degradation products (LaGrega, et al. 1994; Sweet. 1987; US. 1993).

\begin{tabular}{|l|c|c|c|}
\hline \multicolumn{1}{|c|}{ Chemical } & $\begin{array}{c}\mathrm{LD}_{50}, \text { Rat } \\
\mathrm{mg} / \mathrm{kg}\end{array}$ & $\begin{array}{c}\text { Tap Water } \\
\mu \mathrm{g} / \mathrm{l}\end{array}$ & $\begin{array}{c}\text { Carc. } \\
\text { Class }\end{array}$ \\
\hline Formaldehyde & 42 & $730 n$ & $\mathrm{~B}$ \\
Methanol & 7300 & $1800 n$ & \\
1,1-dimethylhydrazine & 265 & $0.026 c$ & $\mathrm{~B}$ \\
1,2-dimethylhydrazine & 36 & $0.0018 c$ & $\mathrm{~B}$ \\
Hydrazine & 59 & $0.022 c$ & $\mathrm{~B}$ \\
RDX & 59 & $0.61 c$ & $\mathrm{C}$ \\
HMX & 1500 & $180 n$ & $\mathrm{D}$ \\
\hline
\end{tabular}

Tap water values are the approximate concentration at which the risk of cancer (c) equals one-in-a-million or a hazard index of 1.0 for non-carcinogenic (n) effects.

A comparison of the $\mathrm{LD}_{50}$ values suggests that the overall toxicity decreases for the degradation of RDX and increases for HMX. A comparison of the tap water values suggest that the carcinogenicity of the degradation products is greater than that of HMX and RDX. Since many of these byproducts can be formed in the environment, it is important that RDX and HMX releases be closely monitored and remediated. 


\section{Chapter 2 \\ Environmental Behavior}

The behavior of RDX and HMX in the environment is an important consideration in the design of treatment processes. Also, an understanding of the environmental fate of HMX and RDX provides clues as to how they can be remediated. One of the major processes affecting the transport of HMX and RDX is their sorption and desorption onto soil and sediment. Interactions of HMX and RDX with the soil affect their mobility and treatability. Major transformation processes affecting HMX and RDX are photolysis and biodegradation. The biodegradation of RDX and HMX in the environment occurs most rapidly in anaerobic zones. Photolysis may occur in surface waters such as lagoons and rivers which are exposed to the sunlight.

\subsection{Sorption/Desorption}

The movement of HMX and RDX in the subsurface is affected by sorption and desorption processes. The sorption and desorption of these contaminants is largely dependent on the organic carbon content $\left(f_{o c}\right)$ of the soil. The simplest method of quantifying the retention of a compound in a soil matrix is the Freundlich equation (Equation 2.1).

$$
S=K_{d} C
$$

Where $\mathrm{S}$ is the amount of compound retained by the soil $(\mathrm{mg} / \mathrm{kg}), \mathrm{C}$ is the compound concentration in solution $(\mathrm{mg} / \mathrm{l})$, and $\mathrm{K}_{\mathrm{d}}$ is the distribution coefficient $\left(\mathrm{cm}^{3} / \mathrm{g}\right)$. The value of $K_{d}$ can be determined by Equation 2.2 (LaGrega, et al. 1994), 


$$
K_{d}=f_{o c} K_{o c}
$$

where $\mathrm{K}_{\mathrm{oc}}$ is the organic carbon partition coefficient, 2.00 for RDX and 0.54 for HMX (Rosenblatt, et al. 1991).

Based on these equations, approximately $2 \%$ of the RDX and $0.5 \%$ of the HMX in a soilwater environment would be sorbed to the soil for every $1 \%$ of organic carbon content. This suggest that sorption will have a minimal retardation effect on the transport of RDX and HMX and that sorption should not be a major factor in the remediation of contaminated soil and groundwater.

The limitation of the Freundlich equation is that it only describes the equilibrium condition and not the kinetics of sorption. There is no data on the sorption and desorption rates of RDX and HMX.

\subsection{Biodegradation}

The biodegradation of RDX and HMX in the environment occurs both aerobically and anaerobically. Anaerobic degradation rates are typically greater than aerobic rates. The most rapid rates of biodegradation of RDX and HMX in the environment should occur in anaerobic zones where other nutrients are present.

RDX was not observed to degrade aerobically in Holston River water by Spanggord, et al. (1980). However, when $1 \%$ river sediment was added to the sample under aerobic conditions, the concentration of $\mathrm{RDX}$ decreased from 10 to $4 \mathrm{ppm}$ in 16 days following a 20 day lag period during which no degradation occurred. Under anaerobic conditions, the concentration of RDX in the river water decreased from $10 \mathrm{ppm}$ to less than $0.1 \mathrm{ppm}$ in 10 days when $30 \mathrm{ppm}$ of yeast 
extract was added to the sample. No anaerobic degradation occurred in samples without yeast extract. Spanggord, et al, (1980) concluded that in order for RDX to degrade anaerobically in river water extra nutrients are required.

No aerobic biodegradation of RDX occurred in samples taken from Louisiana AAP lagoons even when yeast extract was added. RDX biodegradation did occur under anaerobic conditions after several additions of yeast extract and a lag time of 70 days (Spanggord, et al 1983b).

The aerobic biodegradation of HMX and RDX was observed in a sample taken from the effluent line at Holston AAP when 50 ppm yeast extract was added (Spanggord, et al. 1983a). The concentration of HMX decreased from 6.1 to $3 \mathrm{ppm}$ and RDX decreased from 7.0 to 0.1 ppm in 2 days. Several attempts to culture the microorganisms which degraded HMX and RDX failed.

HMX was biodegraded anaerobically in cultures obtained from Holston AAP effluent to which yeast extract was added. The concentration of HMX decreased from 3.5 to less than 0.2 ppm in 3 days in cultures with $50 \mathrm{ppm}$ yeast extract added. Products identified from the aerobic and anaerobic degradation of HMX were the mono- through tetra-nitroso derivatives of HMX which were eventually metabolized to 1,1-dimethylhydrazine (Spanggord, et al. 1983a).

\subsection{Photolysis}

The photolysis of RDX and HMX has been reported as the major transformation process in Holston River water and Louisiana AAP lagoons (Spanggord, et al. 1983a). The photolytic degradation of HMX and RDX can be described by the first-order rate Equation 2.3. 


$$
\ln C=\ln C_{o}-k t
$$

where $\mathrm{Co}(\mathrm{mg} / \mathrm{l})$ is the initial concentration, $\mathrm{k}\left(\mathrm{time}^{-\mathrm{ll}}\right)$ is the degradation constant, $\mathrm{t}$ is time, and $\mathrm{C}(\mathrm{mg} / \mathrm{l})$ is the concentration at time $\mathrm{t}$ (Spanggord, et al 1983a). The photolytic degradation rates of the contaminants are slowed by high turbidity and depth.

Tests were conducted on pure water and lagoon water contaminated with 5 ppm HMX in dishes at a depth of $4 \mathrm{~cm}$ exposed to sunlight for 10 days by Spanggord, et al (1983a). The degradation rates for HMX in the lagoon and pure water were determined to be 0.0099 and 0.019 day $^{-1}$, respectively. RDX degradation rates in the lagoon and pure water were 0.057 and 0.56 day '. The smaller degradation rates in the lagoon water is due to light screening in the lagoon water.

Data for the photolysis of HMX and RDX in Holston river water is presented in Table 2.1. The results show that photolytic degradation decreases with depth and is greatest in the summer, when light intensity is highest. The difference in the degradation rates of RDX and HMX is due to RDX's greater molar absorptivity. Nitrite, nitrate, and formaldehyde were identified as photochemical transformation products of RDX and HMX.

Table 2.1: Photolytic Degradation Rates for HMX and RDX in Holston River Water (Spanggord, et al. 1983a).

\begin{tabular}{|c|c|c|c|c|c|c|c|c|}
\hline & \multicolumn{8}{|c|}{$\mathrm{k}\left(\mathrm{day}^{-1}\right)$} \\
\hline & \multicolumn{4}{|c|}{ RDX } & \multicolumn{4}{|c|}{ HMX } \\
\hline & Spring & Summer & Fall & Winter & Spring & Summer & Fall & Winter \\
\hline 0 & 0.71 & 0.94 & 0.40 & 0.20 & 0.286 & 0.40 & 0.16 & 0.069 \\
\hline 50 & 0.25 & 0.32 & 0.13 & 0.070 & 0.087 & 0.12 & 0.045 & 0.021 \\
\hline 100 & 0.14 & 0.18 & 0.073 & 0.039 & 0.045 & 0.063 & 0.024 & 0.011 \\
\hline 150 & 0.092 & 0.12 & 0.049 & 0.026 & 0.030 & 0.042 & 0.016 & 0.0073 \\
\hline 200 & 0.069 & 0.089 & 0.037 & 0.020 & 0.023 & 0.032 & 0.012 & 0.0055 \\
\hline 250 & 0.055 & 0.072 & 0.300 & 0.016 & 0.018 & 0.250 & 0.010 & 0.0044 \\
\hline 300 & 0.046 & 0.060 & 0.025 & 0.013 & 0.015 & 0.210 & 0.008 & 0.0036 \\
\hline
\end{tabular}




\section{Chapter 3 Treatment Methods}

Several methods of treating RDX and HMX contaminated soil and water have been developed. Most research has focused on the treatment of wastewater generated from munitions manufacturing plants. However, recent research has focused on the remediation of contaminated surface and groundwaters and soils resulting from the manufacture, handling and disposal of munitions.

Carbon adsorption is commonly used to treat munition plant wastewater. Removal efficiencies of greater then $99.5 \%$ by carbon adsorption have been reported (Sublette, et al. 1992).

Several methods of oxidizing RDX and HMX have been studied. The photolysis of RDX in aqueous solution was examined by Kubose and Hoffsommer (1977). A series of studies evaluating different methods of treating the effluent from the Holston Army Ammunition Plant (AAP) provided information about the use carbon adsorption, ultraviolet radiation, ultraviolet radiation and hydrogen peroxide, ultraviolet radiation and ozone, and corona oxidation (Burrows. 1982, 1983; Burrows and Brueggemann. 1986; Kobylinski and Burrows. 1983; Noss and Chyrek. 1984). RDX contaminated waters have also been treated by the addition of oxidizing agents to the water (Sullivan, et al. 1979).

Most of the research examining the biodegradation of RDX and HMX has been done since 1990. Microorganisms capable of degrading HMX and RDX have been identified and 
anaerobic degradation pathways have been proposed (McCormick, et al. 1981; Kaplan. 1993). The anaerobic degradation of RDX has been reported in several studies (Kitts, et al. 1994; McCormick, et al. 1981; Osmon and Klausmeier. 1973; Regan and Crawford. 1994). The biodegradation of RDX under aerobic conditions has only been reported in two studies (Binks, et al. 1995; Knezovich and Daniels. 1991). However, the biodegradation of RDX by white rot fungus also occurs under aerobic conditions (Fernando and Aust. 1990; Sublette, et al. 1992). The biodegradation of HMX has only been observed under anaerobic conditions (Kaplan. 1993; Kitts, et al. 1994; McCormick, et al. 1984).

Composting is commonly used to treat explosive contaminated soils. Numerous laboratory and field tests have achieved degradation efficiencies greater then $90 \%$ for RDX and HMX using a variety of composting materials (Doyle, et al. 1986; Doyle and Kitchens. 1993; Griest, et al. 1990; Isbister, et al. 1982; Williams, et al. 1992). The high degradation efficiencies and moderate costs of composting make it an effective method of treating RDX and HMX contaminated soils.

Other methods of treating RDX contaminated water include using a basic resin which adsorbs the RDX and then degrades it (Hoffsommer, et al. 1977). Coagulation has also been successfully used to remove RDX from contaminated water (Sullivan, et al. 1979).

\subsection{Carbon Adsorption}

Carbon adsorption is a proven method of removing organic contaminants from water. Activated carbon adsorbs organics by a combination of electrical attraction, Van der Waal's forces, the compound's affinity for carbon, and the hydrophobic nature of the contaminant (LaGrega, et al. 1994). Explosives handling facilities have demonstrated that activated carbon 
adsorption can remove greater than $99.5 \%$ of the munitions in pink water. Pink water is the wastewater produced form the manufacture and handling of explosives. The major contaminants of pink water are TNT and RDX, and to a lesser extent HMX (Sublette, et al. 1992).

The adsorption of HMX and RDX by granular activated carbon (GAC) is primarily controlled by Van der Waal's forces. The equilibrium concentration of the contaminant between the water and carbon can be described by the Freundlich equation (Burrows. 1982).

$$
\mathrm{q}_{\mathrm{e}}=\mathrm{KC}^{\mathrm{l} / \mathrm{n}}
$$

Where $\mathrm{q}_{\mathrm{c}}(\mathrm{mg} / \mathrm{mg})$ is the mass of explosive adsorbed per unit weight of carbon, $\mathrm{C}(\mathrm{mg} / \mathrm{l})$ is the final concentration of the contaminant is the water and, $\mathrm{K}$ and $\mathrm{n}$ are dimensionless constants. $\mathrm{K}$ and $n$ can be determined from a plot of $\log C$ versus $\log q_{e}$, made from laboratory data, where $q_{c}$ is the $y$-intercept and $\mathrm{n}$ is the inverse of the slope (Dennis, et al. 1990). In a series of 24-hour batch tests conducted by Burrows (1982) on HMX and RDX individually the Freundlich equations were determined to be:

$$
\begin{aligned}
& \text { HMX: } q_{e}=0.1682 C^{1 / 2.169} \\
& \text { RDX: } q_{e}=0.1118 C^{1 / 2.938}
\end{aligned}
$$

However, these values should not be considered absolute. A batch study by Dennis, et al. (1990) demonstrated the wide range of $\mathrm{K}$ and $\mathbf{n}$ values that can occur for different types of GAC. Values for $\mathrm{K}$ ranged from 0.0012 to 0.052 and values for $1 / \mathrm{n}$ ranged from 0.1 to 0.63 . The wide range of values for each of these parameters can be attributed to differences in the GAC such as surface area and sorption capacity.

Since RDX and HMX are usually found with TNT, carbon adsorption of an explosives mixture was examined by Burrows (1982). It was found that TNT is the most strongly sorbed, 
and that each compound interferes with the sorption of the others. Burrows (1982) assumed that as the contaminated water flows through the GAC, TNT will be adsorbed first, followed by HMX, and finally RDX. Then as treatment continues TNT will displace HMX and RDX from the carbon.

There are several differences between the pink water and explosives contaminated ground and surface waters that must be considered before using GAC for remediation. Pink water has a higher concentration of explosives than contaminated waters and the $\mathrm{pH}$ of pink water is usually acidic, while that of groundwater is neutral or variable. Groundwater is likely to contain other soluble organics, native to the aquifer, which can compete with RDX and HMX for sorption sites (Dennis, et al. 1990).

The main disadvantages of GAC are its high purchase and disposal costs. Since the spent carbon cannot be safely regenerated, it must be disposed of after a single use. The purchase and disposal costs of the GAC required to treat 1000 gallons of pink water have been estimated at $\$ 13.24$ and $\$ 20.78$, respectively (Sublette, et al. 1992). The costs of treating contaminated ground and surface waters should be less due to lower concentrations of explosives. Another factor to be considered is the kinetics of adsorption. While the Freundlich equation describes the equilibrium relationship, which determines the volume of water that can be treated, kinetics will determine the maximum flow rate through the GAC. None of these experiments examined the kinetics of the process.

\subsection{Oxidative Processes}

Oxidation is commonly used to treat waters contaminated with organic compounds. Chemical oxidation is carried out by the addition of oxidizing agents such as ozone, hydrogen 
peroxide, or chlorine. Oxidation may also be done by ultraviolet (UV) radiation. UV treatment is usually used in combination with a chemical oxidant (LaGrega, et al. 1994).

A study by Kubose and Hoffsommer (1977) examined the photolysis of RDX in solution. A tray apparatus, $30 \mathrm{~cm}$ long and $14 \mathrm{~cm}$ wide, was used to study RDX decomposition in laminar flow at various depths. The light source was a 1200 watt medium pressure mercury lamp (220$1367 \mathrm{~nm}$ ) located 1-2 cm above the RDX solution. Results are presented in Table 3.1 .

Table 3.1: Photolysis of RDX in Laminar Flow Tray (Kubose and Hoffsommer. 1977).

\begin{tabular}{|c|c|c|c|c|c|}
\hline Solution & \multicolumn{2}{|c|}{ \% RDX removed at various flow rates (ml/min) } & Initial RDX \\
\cline { 2 - 5 } Depth (cm) & 1000 & 1500 & 2000 & 2500 & Conc. (ppm) \\
\hline 0.5 & 99.9 & 99.8 & 98.7 & 96.9 & 22 \\
1.0 & 99.9 & 99.9 & 98.6 & 96.9 & 39 \\
2.0 & 99.9 & 99.9 & 99.5 & 97.8 & 26 \\
3.0 & 99.9 & 99.8 & 99.6 & 98.9 & 18 \\
\hline
\end{tabular}

Kubose and Hoffsommer (1977) concluded that the removal efficiency of RDX was independent of the solution depth and the decomposition products did not interfere with photolysis. A treatment system was proposed in which the water would flow laminarly up through the box with a photolysis lamp located at the top. This design would allow the maximum exposure time for a given flow rate.

Analysis of photolyzed RDX solution revealed the major products to be the nitrate ion, nitrite ion, formaldehyde, and ammonia. The presence of these compounds indicates cleavage of the RDX ring has occurred. 1-nitroso-3,5 -dinitro-1,3,5-triazacyclohexane was identified as an intermediate which was susceptible to further photolysis.

In experiments on munitions contaminated water the use of UV radiation with and without ozone was studied by Burrows (1983) and Burrows and Brueggemann (1986). To 
conduct the study the contaminated water was continuously circulated through a reactor 6.6 inches in diameter and 78 inches long at $6 \mathrm{l} / \mathrm{min}$. The light source was an 80-watt UV lamp which ran through the center of the reactor to provide maximum UV exposure. These experiments showed that ultraviolet degradation of HMX and RDX obeys mixed zero and first order kinetics described by Equation 3.4.

$$
a \frac{\left(C_{o}-C\right)}{C_{o}}+b \cdot \ln \frac{C_{o}}{C}=k t
$$

Where $C_{0}(m g / l)$ is the initial contaminant concentration, $C(m g / l)$ of the concentration of the contaminant at time $\mathrm{t}, \mathrm{k}$ is the degradation constant, $\mathrm{a}$ is the zero order fraction, $\mathrm{b}$ is the firstorder fraction, and $a+b=1$ (Burrows and Brueggemann. 1986). Values for each of the parameters for RDX are given in Table 3.2.

Table 3.2: Mixed Zero and First Order Rate Parameters for RDX and HMX Decomposition (Burrows and Brueggemann. 1986).

\begin{tabular}{|c|c|c|c|c|c|}
\hline Munition & $\begin{array}{c}\text { Initial Conc. } \\
(\mathrm{mg} / \mathrm{L})\end{array}$ & Conditions & $\begin{array}{c}\text { Zero Order } \\
\text { Fraction }\end{array}$ & $\begin{array}{c}\text { First Order } \\
\text { Fraction }\end{array}$ & $\begin{array}{c}\mathrm{k} \\
\left(\mathrm{min}^{-1}\right)\end{array}$ \\
\hline RDX & 18.61 & ${\mathrm{UV} / \mathrm{O}_{3}}$ & 0.15 & 0.85 & 0.374 \\
RDX & 23.90 & UV only & 0.55 & 0.45 & 0.212 \\
RDX & 17.18 & UV only & 0.75 & 0.25 & 0.197 \\
HMX & 2.67 & UV/O $_{3}$ & 1.0 & 0.0 & 0.363 \\
\hline
\end{tabular}

RDX and HMX were found to have similar degradation rates when exposed to UV and ozone. However, the degradation of HMX occurs by zero-order kinetics while RDX degradation follows mainly first-order kinetics. Degradation products identified from this experiment were s-triazine and nitrous acid. 
Burrows and Brueggemann (1986) conducted an economic analysis to estimate the cost of a full-scale UV radiation treatment system. At full mobilization the system would be able to treat 12.6 MGD. The capital costs were estimated to be $\$ 5,775,000$ and operations costs were estimated at $\$ 1,000,000 / \mathrm{yr}$ (1986 figures). Over the life of a twelve-year remediation project the treatment cost would average to $\$ 0.41 / 1000$ gallons.

The use of UV with and without hydrogen peroxide to treat simulated pink water was studied by Noss and Chyrek (1984). RDX and HMX were exposed to UV light $(253.7 \mathrm{~nm})$ in 60-minute batch studies at $\mathrm{pHs}$ of 5,7 , and 9. It was determined that the degradation rate was independent of the $\mathrm{pH}$ over this range. First-order degradation rates of 0.065 and $0.048 \mathrm{~min}^{-1}$ were calculated for RDX and HMX, respectively.

$\mathrm{UV}-\mathrm{H}_{2} \mathrm{O}_{2}$ studies were carried out in the same apparatus used to study UV-ozone degradation. The results of the treatment of $\mathrm{HMX}$ and $\mathrm{RDX}$ contaminated water with $\mathrm{UV}-\mathrm{H}_{2} \mathrm{O}_{2}$ are in Table 3.3.

Table 3.3: UV- $\mathrm{H}_{2} \mathrm{O}_{2}$ Treatment First-order Degradation Rates for RDX and HMX (Noss and Chyrek 1984).

\begin{tabular}{|c|c|c|}
\hline \multirow{2}{*}{$\% \mathrm{H}_{2} \mathrm{O}_{2}$} & \multicolumn{2}{|c|}{$-\mathrm{k}\left(\mathrm{min}^{-1}\right)$} \\
\hline 5.00 & RDX & HMX \\
1.00 & 0.003 & 0.003 \\
0.10 & 0.066 & 0.011 \\
0.01 & 0.087 & 0.041 \\
\end{tabular}

Noss and Chyrek (1984) concluded that $\mathrm{H}_{2} \mathrm{O}_{2}$ may be used to increase the degradation rates of RDX and HMX when applied in initial concentrations of 0.01 to $0.03 \%$. At greater concentration $\mathrm{H}_{2} \mathrm{O}_{2}$ is inhibitory. It is recommended that pilot-scale studies be conducted to determine the effects of substances in actual contaminated waters. 
RDX and HMX are both susceptible to UV degradation; however there are factors that can interfere with the process. Substances which absorb UV radiation and interfere with decomposition must be minimal, and the turbidity of the wastewater must be low enough for the UV radiation to penetrate. Since these factors are site specific they must be evaluated in each case. Also, the degradation products which result must be less harmful or easier to remove from the waste stream.

The use of corona oxidation to treat HMX and RDX contaminated water was studied by Kobylinski and Burrows (1983). Corona oxidation uses electrolysis to destroy contaminants. An electric current is applied across two electrodes placed in the contaminated water. Since reactions only occur at the electrodes, the reaction rate is limited by the surface area of the electrode. To enhance the process, graphite fiber particles are added to the mixture which is continuously stirred; this is known as the Innova process. The graphite particles become charged as they move through the electrical field. When a charged particle collides with a molecule, electrons are transferred causing an electrochemical reaction. Two hour batch tests were conducted on HMX and RDX individually and in a mixture with TNT, hexahydro-1(N)-acetyl3,5-dinitro-1,3,5-triazine (TAX), and octahydro-1(N)-acetyl-3,5,7-trinitro-1,3,5,7-tetrazocene (SEX). Results are presented in Table 3.4.

The degradation of both compounds occurred by first-order kinetics. RDX and HMX were reduced below their detection limits in the two hours, both individually and in the mixture. However, the degradation of the compounds is slower in mixture. No degradation products were identified. 
Table 3.4: Initial Concentrations and First-order Degradation Rates of HMX and RDX in Corona Oxidation Study (Kobylinski and Burrows. 1983).

\begin{tabular}{|l|c|c|c|c|}
\hline & Munition & Run & $\mathrm{C}_{\mathrm{o}} \mathrm{mg} / \mathrm{l}$ & $-\mathrm{k} \mathrm{min}^{-1}$ \\
\hline Individual & $\mathrm{RDX}$ & 1 & 25.84 & 0.038 \\
& & 2 & 28.10 & 0.030 \\
\cline { 2 - 5 } & $\mathrm{HMX}$ & 1 & 4.73 & 0.047 \\
& & 2 & 4.58 & 0.056 \\
\hline Mixture & $\mathrm{RDX}$ & 1 & 22.97 & 0.029 \\
& & 2 & 27.56 & 0.033 \\
\cline { 2 - 5 } & $\mathrm{HMX}$ & 1 & 3.60 & 0.020 \\
& & 2 & 5.86 & 0.019 \\
\hline
\end{tabular}

The use of UV with an oxidant was chosen over carbon adsorption as the remediation strategy at the Bangor Naval Submarine Base for the treatment of contaminated groundwater (US 1991). UV radiation with oxidation was chosen because it was an innovative technology which reduced the amount of contamination.

The oxidation of RDX by potassium dichromate, potassium permanganate and calcium hypochlorite was reported by Sullivan, et al (1979). Fifty (50) mg/l RDX was completely oxidized by the addition of $1000 \mathrm{mg} / \mathrm{l}$ of $\mathrm{Ca}(\mathrm{OCl})_{2}, \mathrm{~K}_{2} \mathrm{Cr}_{2} \mathrm{O}_{7}$, and $\mathrm{K}_{2} \mathrm{MnO}_{4}$ in 24,48 and 72 hours, respectively. The oxidative products were not identified. Remediation of contaminated waters with these oxidants is not feasible due to the long reaction times.

\subsection{Biodegradation}

Before discussing the biodegradation of HMX and RDX, something first needs to be said about the use of bioremediation to treat hazardous waste. There is a great deal of research currently being done in the area of bioremediation to overcome environmental, physiological and chemical barriers. Bioremediation offers an alternative to other forms of treatment which only move the contaminant from one media to another or require expensive energy sources to destroy 
the contaminants. The ultimate goal of bioremediation is to transform the organic contaminants into biomass and innocuous end-products such as carbon dioxide and ammonia.

Bioremediation can be accomplished in situ or ex situ. In situ remediation involves the stimulation of the indigenous subsurface microorganisms to enhance the degradation of contaminants. However, in some cases specialized microorganisms capable of degrading the contaminants can be introduced into the subsurface. In order for in situ bioremediation to be feasible there are two main criteria. First, the subsurface must be permeable enough to allow the spread of nutrients. A hydraulic conductivity $(\mathrm{K})$ of $10^{-4} \mathrm{~cm} / \mathrm{sec}$ or greater is considered sufficient (Thomas and Ward. 1989). Second, organisms which can degrade the contaminant must be present. To determine if the subsurface microorganisms can metabolize the contaminants laboratory studies need to be conducted on samples from the site.

The treatment of HMX and RDX by ex situ bioremediation involves either composting or bioreactors. Composting as it is used to treat explosives contaminated soil is discussed in the next section. Bioreactors can be used to treat contaminated waters. The contaminated water flows through a reactor containing microbes which will degrade the contaminants. A bioreactor provides a more ideal environment for the microorganisms than the subsurface, because factors such as temperature, contaminant concentration, and the addition of nutrients can be better controlled. The treatment for HMX and RDX contaminated groundwater with bioreactors is limited by the desorption of the contaminants from the soil, like all pump-and-treat technologies. The microbial transformation of RDX was first studied in the 1970s. Osmon and Klausmeier (1973) noticed the disappearance of RDX during soil enrichment studies, but had no proof of microbial degradation. Soli (1973) investigated the transformation of RDX under anaerobic conditions. The concentration of RDX decreased from $20 \mathrm{mg} / \mathrm{l}$ to $0.6 \mathrm{mg} / \mathrm{l}$ over six 
days in the presence of a mixed culture of phototrophic bacteria consisting of several species of Chromatium, Rhodospirillum, and Rhodopseudomonas.

In a study by McCormick, et al., (1981) the biodegradation of RDX by a microbial consortia obtained from anaerobic and activated sewage sludge were examined. Cultures made from a nutrient broth contaminated with RDX at concentrations of 50 and $100 \mu \mathrm{g} / \mathrm{ml}$ inoculated with anaerobic sewage sludge were incubated at $37^{\circ} \mathrm{C}$. Degradation of RDX was complete within 7 days in the culture containing $50 \mu \mathrm{g} / \mathrm{ml} \mathrm{RDX.} \mathrm{No} \mathrm{data} \mathrm{was} \mathrm{provided} \mathrm{for} \mathrm{samples}$ containing $100 \mu \mathrm{g} / \mathrm{ml}$ RDX. It should be noted that the concentration of $100 \mu \mathrm{g} / \mathrm{ml}$ exceeds the solubility of RDX at $37^{\circ} \mathrm{C}$. There was no change in the RDX concentration in cultures that were inoculated with activated sewage sludge and incubated aerobically.

Analysis of the reaction mixture by HPLC indicated the formation of intermediates during the degradation of RDX. McCormick, et al, (1981) initially suggest that because the transformation of RDX occurs only under anaerobic conditions that the intermediates formed would be reduced forms of RDX. Intermediates from 2 to 3 day old cultures were identified as hexahydro-1-nitroso-3,5-dinitro-1,3,5-triazine (MNX) and hexahydro-1,3-dinitroso-5-nitro-1,3,5triazine (DNX), with the GC/MS. Hexahydro-1,3,5-trinitro-1,3,5-triazine (TNX) was identified as an intermediate in an 8 day old culture. The identification of these reduced forms of RDX verified their initial suggestion. Other intermediates or products that were identified include methanol formaldehyde, hydrazine, 1,1-dimethylhydrazine, and 1,2-dimethylhydrazine.

As RDX disappeared there was a sequential buildup of the mono-, di-, and trinitroso analogs of RDX. Using this information a pathway for the degradation of RDX was suggested in Figure 3.1. This pathway shows several by-products which have not yet been identified. A 
comparison of the $\mathrm{LD}_{50}$ and carcinogenicity values of $\mathrm{RDX}$ and the degradation end-products in Section 1.4 shows a decrease in the toxicity, but an increase in the carcinogenicity.

McCormick, et al, (1981) concludes that the bioremediation of RDX contaminated waste must include anaerobic treatment. Due to the presence of high levels of nitrates in munitions waste, $\mathrm{RDX}$ can be treated in an anaerobic denitrification so the $\mathrm{NO}_{2}$ groups on the RDX

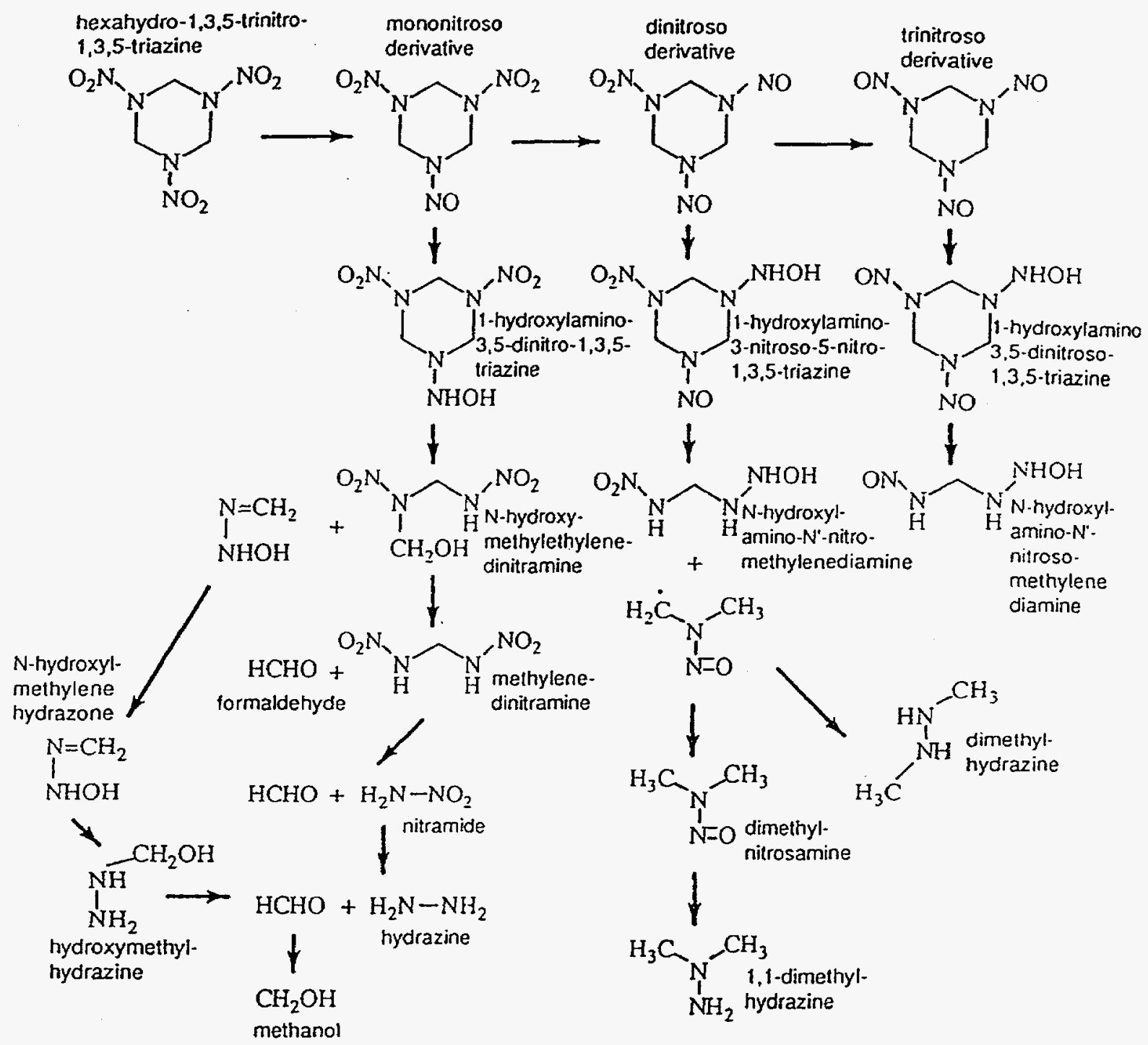

Figure 3.1: Proposed Pathway for the Anaerobic Biodegradation of RDX (McCormick, et al. 1981) 
molecule can serve as an electron acceptor. This should be followed by an aerobic stage to oxidize methanol to carbon dioxide.

HMX is also biodegradable under anaerobic conditions at $50 \mathrm{mg} / \mathrm{l}$, although rates are slower than those for RDX. Intermediates identified from the degradation of HMX include mono- and di-nitroso derivatives. A pathway proposed for the formation of these derivatives is shown in Figure 3.2 (Kaplan. 1993).<smiles>O=NN1CN([N+](=O)[O-])CN([N+](=O)[O-])CN([N+](=O)[O-])CN([N+](=O)[O-])C1</smiles><smiles>O=NN1CN(N2CN(N=O)CN([N+](=O)[O-])CN([N+](=O)[O-])C2)CN([N+](=O)[O-])CN([N+](=O)[O-])C1</smiles>

Figure 3.2: Proposed Pathway for the Formation of mono- and di-nitroso-derivatives of HMX (Kaplan. 1993).

A study by McCormick, et al, (1984) examined the biodegradation of RDX and HMX in continuous culture systems. Bacteria for the cultures were obtained from anaerobic sewage sludge. The culture was continuously supplied with a liquid medium contaminated with RDX and HMX, containing molasses, nutrient broth or acid-hydrolyzed sludge as a carbon source. Throughout the experiment the extent of RDX degradation approached 100\%. The transformation of HMX was always less than that of RDX, reaching highs of 90,85 , and $90 \%$ for molasses, nutrient broth and acid-hydrolyzed sludge, respectively. McCormick, et al, (1984) 
concluded that RDX and HMX can be treated by anaerobic biodegradation. However, a supplemental carbon source is needed to maintain a high level of biotransformation.

Knezovich and Daniels (1991) developed a bench-scale continuous flow-stirred tank reactor for the treatment of RDX contaminated water under aerobic conditions. This was the first time the aerobic biodegradation of RDX was reported. Unlike anaerobic degradation, no potentially carcinogenic byproducts were formed. The results of this study are being used to design a treatment system to be tested in the field.

A study by Fernando and Aust (1991) examined the biodegradation of RDX in soil and water samples by the white rot fungus, Phanerochaete chrysosporium, under nitrogen-limiting conditions. Liquid cultures were inoculated with 1.25 nmoles $\left[{ }^{14} \mathrm{C}\right] \mathrm{RDX} / 10 \mathrm{ml}$. After 30 days of incubation $67 \%$ of the initial $\left[{ }^{14} \mathrm{C}\right] \mathrm{RDX}$ had been mineralized to $\mathrm{CO}_{2}$. Approximately $94 \%$ of the initial $\left[{ }^{14} \mathrm{C}\right] \mathrm{RDX}$ was recovered and only $4 \%$ remained undegraded. In control cultures where $P$. chrysosporium was not added, but all other parameters remained constant, $97-98 \%$ of the initial RDX remained undegraded.

Soil samples were prepared from 10 grams of soil contaminated with 1.25 nmoles of $\left[{ }^{14} \mathrm{C}\right]$ RDX. The soil used was an agricultural silt loam with an organic matter content of $3.62 \%$ and an organic carbon content of $2.10 \%$. The contaminated soil was mixed with 6.7 grams of ground corncobs which had been inoculated with $P$. chrysosporium. Control cultures were identical except that the ground corncobs were not inoculated with $P$. chrysosporium. After 30 days of incubation, $76 \%$ of the initial ${ }^{14} \mathrm{C}$ was recovered as ${ }^{14} \mathrm{CO}_{2}$. Approximately $90 \%$ of the initial radioactivity was accounted for and only $4 \%$ of the $\left[{ }^{14} \mathrm{C}\right]$ RDX remained undegraded. In the control cultures, $99 \%$ of the RDX remained unmetabolized. 
While this experiment did show that $P$. chrysosporium is capable of mineralizing RDX in both soil and water samples, none of the intermediate metabolites or other end-products were identified. This is a concern because it is known that many of the products formed during the anaerobic biodegradation of RDX are mutagenic or carcinogenic (McCormick, et al. 1981). Further studies need to be done to identify the products formed during the mineralization of RDX and to propose a degradation pathway.

The generation of ${ }^{14} \mathrm{CO}_{2}$ from the radio-labeled RDX shows that $P$. chrysosporium is able to cleave the RDX ring. The success of this experiment suggests that use of $P$. chrysosporium to treat RDX contaminated soil and water should be further evaluated. Also, the use of $P$. chrysosporium to treat HMX contamination should be studied. An area of concern is the $10 \%$ of the $\left[{ }^{14} \mathrm{C}\right]$ RDX which was unextractable from the soil mixture. Since this material could not be identified it would be useful to examine the change in the amount of unextractable content over the incubation period. This information could be used to determine if the sorbed contaminant is being degraded.

The feasibility of using a bioreactor with $P$. chrysosporium to treat pink water was studied by Sublette, et al, (1992). The bioreactor system was evaluated as an alternative treatment to the activated carbon absorption currently being used to treat the pink water. The use of activated carbon is limited because it cannot be safely regenerated.

Two bench-scale reactors with a liquid capacity of two liters each were used to conduct the experiment. Each reactor was partitioned into four sections with two $17.8 \mathrm{~cm}$ disks, mounted on a horizontal shaft, to serve as a surface for the fungus in each section. The partitions in the reactors contained holes which could be plugged so that the reactors could be operated in both a batch and a continuous mode. 
In the batch mode, 12 nitrogen-limiting mediums containing RDX or RDX and TNT were tested. Three of the batches used actual pink water, two contained only RDX, and seven used a simulated pink water. In the two batches which contained only RDX, the concentration of RDX decreased to approximately $50 \%$ of the initial concentration over 65 hours. However, in those batches which contained both RDX and TNT it appeared that the concentration of RDX increased with time. It is believed than an intermediate metabolite formed during the degradation of TNT that had a similar residence time to RDX in the HPLC interfered with the analysis. Attempts to separate the TNT degradation products from RDX, for analysis, were unsuccessful.

In the continuous flow experiments, a working medium with varying concentrations of TNT and RDX was used at a flow rate of $1.5 \mathrm{ml} / \mathrm{min}$. When simulated wastewater was fed into the reactor over a period of 163 hours, the apparent removal of RDX averaged 65-78\%. However, the intermediate formed from the degradation of TNT may have once again interfered with the analysis of samples, making an exact determination of RDX removal impossible.

The proposed treatment process consists of a bioreactor using $P$. chrysosporium to remove the majority of the contaminants, followed by an activated carbon finishing step. The objective is that the bioreactor would reduce the cost of disposal of the contaminated carbon enough to make the bioreactor system economically beneficial. The entire treatment scheme is shown in Figure 3.3.

A tank prior to the bioreactor would serve as an equalization basin and for screening out any grit. This tank would also serve for mixing added nutrients needed for fungal growth and chemicals to adjust the $\mathrm{pH}$ to 6 . The bioreactor would be a rotating biological contactor (RBC) using $P$. chrysosporium to remove TNT to $1 \mathrm{mg} / \mathrm{L}$ and $70 \%$ of the other organic contaminants, 


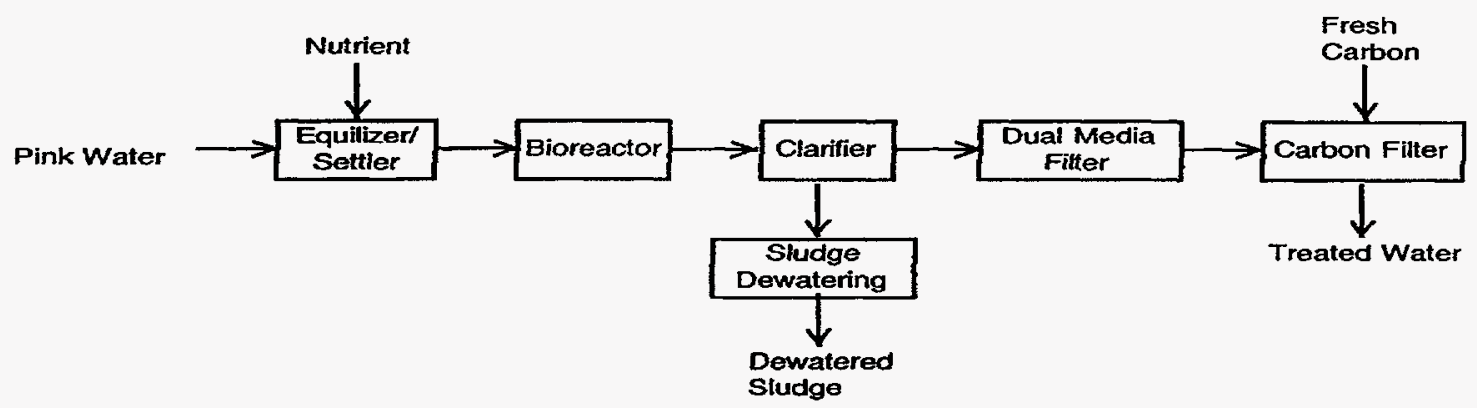

Figure 3.3: Block Flow Diagram of Proposed Bioreactor/Activated Carbon System for the Treatment of Pink Water (Sublette, et al. 1992).

primarily RDX and HMX. The reactor would be designed for a retention time of 24 hours.

Sludges from the RBC would be dewatered and treated separately. The RBC effluent is pumped through a sand/coal filter to remove any suspended solids. The filtered water is then polished in two GAC beds in series to remove any remaining organics. The spent carbon is incinerated at an approved facility. The treated water could be discharged or used in the plant.

A cost analysis was done to compare the RBC system with carbon absorption. It was determined that the total installed cost of the bioreactor system would be approximately 3-4 times that for the carbon absorption system. However, the operating cost of the bioreactor system would only be $20-25 \%$ that of the activated carbon process, resulting in a return of the initial installment costs in 12 to 18 months.

The analysis shows that $P$. chrysosporium can be used as a cost effective method of treating pink water. However, the low concentrations of RDX in contaminated surface and ground waters may be more difficult. Additional nutrients will be needed to support fungus growth and removal efficiencies may be lower. The study by Fernando and Aust (1991) did 
show that RDX at a concentration of $0.28 \mathrm{mg} / \mathrm{L}$ could be effectively mineralized by $P$. chrysosporium over 30 days.

In a study by Kitts, et al, (1994) three species of the family Enterobacteriaceae that were able to anaerobically transform RDX and HMX were isolated from high-explosives contaminated soil. All three species are able to transform HMX and RDX; however only the $M$. morganii could transform HMX in the presence of RDX.

Bacteria from an explosives contaminated soil sample were inoculated into a nutrient broth containing $0.33 \mathrm{mM} \mathrm{RDX}$ and $0.05 \mathrm{mM} \mathrm{HMX}$. During the three-week incubation time both RDX and HMX were completely transformed. The bacteria capable of transforming RDX and HMX were isolated from this culture. The species Morganella morganii and Provedencia rettgeri completely transformed RDX and Citrobacter freundii partially transformed RDX. The degradation of RDX and HMX occurred solely under oxygen depleted conditions. All three species released ${ }^{14} \mathrm{CO}_{2}$ when incubated with $\left[{ }^{14} \mathrm{C}\right] \mathrm{RDX}$, indicating ring breakage. $P$. rettgeri and M. morganii transformed all of the initial RDX with in 45 days, but $C$. freundii only transformed $85 \%$ of the initial RDX. However, the extent of mineralization was less than $10 \%$ of the initial concentration for all three bacteria.

Each isolate is also capable of transforming HMX; however the process is slower and less complete than for RDX. After 45 days of incubation, M. morganii, P. rettgeri, and C. freundii transformed approximately $60 \%, 60 \%$, and $50 \%$ of the initial HMX, respectively.

The identification of metabolites by HPLC revealed the presence of the nitroso derivatives of HMX and RDX. The accumulation of mono and dinitroso- derivatives of RDX reached a maximum within 10 days and then decreased. P. rettgeri and $M$. morganii each reduced the concentration of nitroso derivatives to below $5 \%$ of the initial RDX concentration. 
Their presence suggest the degradation of HMX and RDX may occur by the previously proposed pathways (McCormick, et al. 1981; Kaplan. 1993).

A study by Regan and Crawford (1994) isolated a strain of Clostridium bifermentans that can anaerobically degrade RDX in pure culture without the need of an added reductant. The transformation of RDX was concurrent with an increase in the cell number. The cell number of the culture reached its maximum as the RDX concentration reached its minimum. The transformation of RDX was essentially complete within 23 hours. This relatively short time, when compared to other studies, is attributed to the rich carbon supplement supplied by the $C$. bifermentans. The products resulting from the transformation of RDX were not identified.

A bacterium, Stenotrophomonas maltophilia PB1, capable of degrading RDX under aerobic and nitrogen-limiting conditions, was isolated from a culture which used RDX as a sole source of nitrogen for growth (Binks, et al. 1995). The bacterium was unable to use HMX as a sole source of nitrogen. S. maltophilia PB1 was isolated from a mixed bacterial consortia obtained from soils that had been extensively exposed to RDX and HMX. Cultures were grown on mediums using $\mathrm{NH}_{4} \mathrm{NO}_{3}$ and $\mathrm{RDX}$ as sources of nitrogen. Colonies which grew on the solid medium were inoculated into a liquid medium containing RDX as the sole nitrogen source. Only S. maltophilia PB1 was capable of utilizing RDX as a sole nitrogen source.

The specific growth rate of S. maltophilia PB1 was $0.023 / \mathrm{hr}$ in an RDX containing liquid. When $\mathrm{NH}_{4} \mathrm{Cl}$ was the sole nitrogen source, the growth yield of $S$. maltophilia was $63.1 \pm 2.0 \mathrm{~g}$ of protein per mole of N. S. maltophilia grown on RDX as a sole nitrogen source had a growth yield of $29.2 \pm 4.4 \mathrm{~g}$ of protein per mole of $\mathrm{N}$. Comparing the two growth yields suggest that only three of the possible six nitrogen atoms were used by S. maltophilia PB1 grown on RDX. 
For the aerobic degradation of RDX to occur, an alternative carbon source was needed, implying that a large amount of reducing power is required.

During cell growth the concentration of RDX in the medium decreased and the formation of a precipitate was observed. The precipitate formed during the degradation of RDX is thought to be a breakdown product of 1-acetylhexahydro-3,5-dinitro-1,3,5-triazine, which is a known contaminant of RDX. One degradation product that was isolated from the liquid medium was tentatively identified by mass spectroscopy and ${ }^{1} \mathrm{H}$ NMR analysis as methylene-N(hydroxymethyl)-hydroxylamine-N'-(hydroxymethyl)nitroamine, Figure 3.4. This metabolite did not accumulate and is assumed to be further metabolized by another reaction.

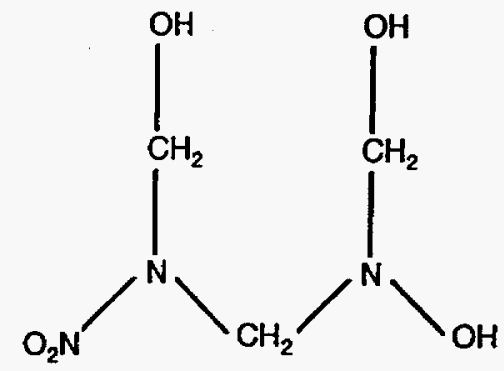

Figure 3.4: Methylene-N-(hydroxymethyl)-hydroxylamine-N'-(hydroxymethyl)nitroamine (Binks, et al. 1995).

The results of these studies show that the biological treatment of RDX and HMX contamination is possible. Treatment by anaerobic biodegradation and P. chrysosporium are the most promising methods, but anaerobic degradation is problematic due to the production of harmful metabolites. Research into the biodegradation of HMX is lacking. Since, HMX and RDX are always found together work needs to be done to determine if the treatment methods used for RDX can also be used for HMX. 
A summary of the data from those studies which provided information about the extent of degradation is presented in Table 3.5.

Table 3.5: Summary of Biodegradation Studies.

\begin{tabular}{|c|c|c|c|c|c|c|}
\hline Study & Microorganism & Conditions & Munition & $\begin{array}{l}\text { Initial Conc. } \\
\text { ppm }\end{array}$ & $\begin{array}{c}\% \\
\text { Reduction }\end{array}$ & $\begin{array}{l}\text { Time } \\
\text { days }\end{array}$ \\
\hline $\begin{array}{l}\text { McCormick et al. } \\
1981\end{array}$ & N/A & Anaerobic & RDX & 50 & 100 & 7 \\
\hline $\begin{array}{l}\text { Fernando and Aust } \\
1991\end{array}$ & P. chrysosporium & Aerobic & RDX & 0.0278 & 96 & 30 \\
\hline Sublette et al. 1992 & P. chrysosporium & Aerobic & RDX & 41 & 56 & 2.7 \\
\hline Kitts et al. 1994 & $\begin{array}{c}\text { M. morganii } \\
\text { M. morganii } \\
\text { P. rettgeri } \\
\text { P. rettgeri } \\
\text { C. freundii } \\
\text { C. freundii }\end{array}$ & $\begin{array}{l}\text { Anaerobic } \\
\text { Anaerobic } \\
\text { Anaerobic } \\
\text { Anaerobic } \\
\text { Anaerobic } \\
\text { Anaerobic }\end{array}$ & $\begin{array}{l}\text { RDX } \\
\text { HMX } \\
\text { RDX } \\
\text { HMX } \\
\text { RDX } \\
\text { HMX }\end{array}$ & \begin{tabular}{|c|}
73 \\
14.81 \\
73 \\
14.81 \\
73 \\
14.81
\end{tabular} & $\begin{array}{c}100 \\
60 \\
100 \\
60 \\
85 \\
50\end{array}$ & $\begin{array}{l}27 \\
45 \\
26 \\
45 \\
45 \\
45\end{array}$ \\
\hline Binks et al. 1995 & S. maltophilia & Aerobic & RDX & 66.6 & 100 & 7.1 \\
\hline
\end{tabular}

\subsection{Soil Composting}

It has been estimated that there are approximately $1,000,000 \mathrm{yd}^{3}$ of munitions contaminated soil in the US (Griest, et al. 1990). Composting is a biological process that utilizes the ability of bacteria and fungi to degrade organic compounds in soils, sediments, and sludges. The microorganisms use the carbon and nitrogen of the organics to synthesize biomass creating inorganic and organic compounds, and heat as by-products. Composting results in higher degradation rates than those found in the normal soil environment, due to the diverse microbial population and the increased temperature and oxygen supply.

Composting is accomplished by mixing the contaminated soil with nutrients and bulking agents that have a high organic content such as manure, animal bedding, corn stalks, or hay. Three types of composting technology are used: windrow, aerated static pile, and mechanical in 
vessel. The method chosen depends on the cost and the amount of control needed. As the technology level increases, operation costs and process control increases.

Several laboratory and field studies have shown that composting of HMX and RDX contaminated soils and sediments is an effective remediation strategy. Reductions in HMX and RDX concentrations of over $90 \%$ have been achieved; however, these values do not truly represent the mineralization due to the sorption of HMX and RDX onto the soil and the formation of intermediates.

In laboratory and greenhouse studies by Isbister, et al, (1982) the composting of RDX contaminated soil was examined. The soil used in the study was chosen for its relatively low capacity to adsorb RDX ( $1 \%$ organic matter), producing "worst case" results in leaching tests. However, this probably also resulted in higher degradation rates, since the RDX would be more readily available to the microbes.

The laboratory compost was a mixture of alfalfa, horse feed, seed, and soil. The seed was a compost of alfalfa, horse feed, and sewage sludge for microorganisms. The compost was incubated at $55^{\circ} \mathrm{C}$ and aerated continuously. The RDX concentration decreased by $31.2 \%$ after three weeks and $78.3 \%$ after six weeks. Approximately $67 \%$ of the radio-labeled RDX was recovered as ${ }^{14} \mathrm{CO}_{2}$, indicating a significant amount of ring cleavage. No RDX metabolites were identified in the compost extracts. It was assumed that any intermediates formed during degradation were rapidly metabolized to $\mathrm{CO}_{2}$.

The compost in the greenhouse study was composed of alfalfa, horse feed, horse manure, and contaminated soil. Alfalfa and hay were added to the compost during the six-week study to maintain the elevated temperature. The composts were aerated by forced aeration and mixed 
frequently to maintain aerobic conditions. The RDX concentration in the compost decreased $61 \%$ in three weeks and $82 \%$ in six weeks.

Leaching tests were performed by extracting $50 \mathrm{~g}$ compost samples with distilled water for 20 hours. The RDX concentration in the water leachate decreased significantly during the study from $124 \mathrm{ppm}$ initially to 52.5 and $13 \mathrm{ppm}$ at three and six weeks, respectively.

Laboratory and pilot-scale composting studies were conducted on TNT, HMX, RDX, and N-methyl-N,2,4,6-tetranitroanile (tetryl) contaminated sediment from the Louisiana AAP by Doyle et al (1986). Laboratory studies were conducted with ${ }^{14} \mathrm{C}$-tracers to evaluate the degradation of the explosives, in two different types of composts, at soil loading rates of 10,18 , and $25 \%$. The first compost consisted of chopped alfalfa hay, horse feed, and seed. The seed was material from a hay-horse feed mixture, previously composted to supply microorganisms. The second compost was made from pine wood shavings and a mixture of activated and anaerobic sewage sludge with ferric chloride and lime added. The average concentration of the explosives in the sediment were 114,600 ppm TNT; 64,205 ppm RDX; 7,043 ppm HMX; and 5,022 ppm tetryl.

Degradation of RDX and HMX was observed at soil loading rates of 10 and $18 \%$. RDX degraded rapidly in both types of composts at a $10 \%$ loading level and was almost completely transformed in 10 weeks. Significant amounts of ${ }^{14} \mathrm{CO}_{2}$ were evolved from compost spiked with radio-labeled RDX. HMX did not degrade in the hay-horse feed mixture, but reductions of 30$50 \%$ were observed in the sewage sludge composts over a ten-week period. The degradation rates of both RDX and HMX decreased as the soil loading rate increased. No toxic by-products accumulated in the compost. 
The contaminated sediment used in the pilot-scale test contained 11.5\% TNT, $6.0 \%$ RDX, $0.16 \% \mathrm{HMX}$, and $0.5 \%$ tetryl on a dry weight basis. A third compost mixture of horse manure, hay, and sawdust made from stable bedding material was also evaluated in the pilotscale study. The hay-horse feed, horse manure-hay-sawdust, and sewage-sludge composts were mixed with contaminated sediment at loading rates of 11,11 , and $16 \%$, respectively.

Transformation of RDX and HMX in both the hay-horse feed and horse manure-haysawdust composts was high. In 7 weeks the concentrations of RDX and HMX were reduced by 83.2 and $71.9 \%$, respectively, in the hay-horse feed composts. Half-lives of RDX and HMX in this compost were determined to be 3.0 and 4.7 weeks, respectively. The RDX and HMX concentration in the horse manure-hay-saw dust composts decreased $94 \%$ and $81 \%$, respectively, in 7 weeks. Half-lives of RDX and HMX in this compost were determined to be 2.5 and 3.3 weeks, respectively. Degradation was insignificant in the sewage sludge compost mixed with contaminated sediment. Doyle et al (1986) proposed that degradation did not occur in the sewage sludge pilot-scale compost because the temperature remained below $50^{\circ} \mathrm{C}$.

Doyle et al (1986) concluded from this study that RDX and HMX can be rapidly degraded by composting. Materials used in the hay-horse feed compost were expensive, but cost can be reduced with the use of locally available products such as bedding material. It was estimated that the cleanup of the contaminated sediment at Louisiana AAP would require the composting of 16,133 cubic yards of soil, at an estimated cost of $\$ 2,431,150$ (using 1986 figures).

Further composting studies were conducted on contaminated sediment from Louisiana AAP by Williams et al (1992). The degradation of TNT, HMX, RDX, and tetryl was examined under mesophilic $\left(35^{\circ} \mathrm{C}\right)$ and thermophilic $\left(55^{\circ} \mathrm{C}\right)$ composting conditions. The compost mixture 
was made from contaminated sediment, alfalfa, straw, and horse feed. The sediment used in the study was contaminated with explosives at the following concentrations: $56,800 \mathrm{mg} / \mathrm{kg}$ TNT; $17,900 \mathrm{mg} / \mathrm{kg} \mathrm{RDX} ; 2,390 \mathrm{mg} / \mathrm{kg} \mathrm{HMX}$; and $650 \mathrm{mg} / \mathrm{kg}$ tetryl. After 153 days of thermophilic composting, the concentrations of RDX and HMX were reduced $99.7 \%$ and $98.9 \%$, respectively. First-order half-lives under thermophilic conditions were calculated to be 17 days for RDX and 23 days for HMX. The final concentrations of RDX and HMX in the mesophilic compost were not reported, but the concentration of all four contaminants was reduced from 16460 to 326 $\mathrm{mg} / \mathrm{kg}$. First-order half-lives in the mesophilic compost were determined to be 30 and 42 days for RDX and HMX, respectively.

Toxicity tests were performed on the thermophilic and mesophilic composts from a previous study by Griest, et al (1990). The compost material from the study was evaluated for toxicity to fathead minnow larvae and Ceriodaphnia dubia, and the Ames test was used to evaluate the mutagenicity. The composts were extracted using the Environmental Protection Agency's synthetic precipitation leach test (CCLT for Clean Closure Leach Test) and the toxicity characteristic leaching procedure (TCLP). The main constituents in leachate were TNT, RDX, and HMX.

The toxicity of the leachate from both composts was low, but the toxicity of the mesophilic compost leachate was 2 to 3 times that of the thermophilic compost leachate. The solvent extracts were found to be considerably more toxic than the aquatic leachate. The concentration of HMX in both leachates was below the health advisory standards mentioned in Section 1.4, but the concentration of RDX exceed the standards in both the CCLT and TCLP leachates. While the low toxicity results are favorable it could not be determined if the toxicity of the contaminated sediment was reduced since none was available from the study. The 
mutagenic activity of the leachates was relatively low. Approximately $37 \%$ of the mutagenic activity could be attributed to the TNT present in the leachate.

In a study by Doyle and Kitchens (1993) soil from the Pantex Plant was used to evaluate composting as a remediation method for RDX, HMX, triaminotrinitrobenzene (TATB), and pentaerythritoltetranitrate (PETN) contamination. In laboratory tests uncontaminated soils samples were spiked with $220 \mu \mathrm{g} / \mathrm{g}$ RDX, $220 \mu \mathrm{g} / \mathrm{g}$ HMX, $400 \mu \mathrm{g} / \mathrm{g}$ PETN, and $2700 \mu \mathrm{g} / \mathrm{g}$ TATB. Each compost contained a different ${ }^{14} \mathrm{C}$-labeled explosive. Three compost mixtures were made containing 20,30 , and $40 \%$ of the spiked soil. The laboratory and pilot-scale composts were made from horse feed, alfalfa, horse manure, and spiked soil. The composts were incubated for six weeks at $60-65^{\circ} \mathrm{C}$ and aerated continuously.

RDX degradation in the compost was rapid. Within 3 weeks, less than $5 \%$ of the total radioactivity could be detected in the soil, and no ${ }^{14} \mathrm{C}$-degradates could be detected. After six weeks no radioactivity could be detected in the soil. The majority of ${ }^{14} \mathrm{CO}_{2}$ production from the compost occurred during the first two weeks of study. The rate of RDX degradation did not decrease with increased soil loading.

The degradation of HMX in the compost was similar to RDX. Degradation of HMX was rapid; less than $7 \%$ of the initial radioactivity could be detected in the majority of the samples by three weeks. The majority of ${ }^{14} \mathrm{CO}_{2}$ evolved occurred during the first three weeks. The rate of HMX degradation was not noticeably affected by changes in the soil loading rate.

Pilot-scale composts were mixed with soil contaminated with $220 \mu \mathrm{g} / \mathrm{g}$ RDX, $220 \mu \mathrm{g} / \mathrm{g}$ HMX, $400 \mu \mathrm{g} / \mathrm{g}$ PETN, and $1500 \mu \mathrm{g} / \mathrm{g}$ TATB. Degradation of HMX and RDX was rapid. RDX could not be detected in the compost by day 12 , and HMX could not be detected by day 14 . 
The cost of composting of the contaminated ditches at the Pantex site was estimated to be $\$ 1,324,979$ or $\$ 226 /$ ton (1993 figures), and would take one year. The cost of composting would be approximately $20 \%$ cheaper than the estimated cost of incineration at $\$ 272 /$ ton (Doyle and Kitchens. 1993). In contrast with other composting studies the degradation rate was not affected by changes in the soil loading. This probably was due to the considerably lower concentrations of explosives used in this study.

Composting of HMX and RDX contaminated soils is an extremely promising technology. The degradation rate of HMX and RDX is dependent on the their concentration in the soil and the soil loading rate. Also, the cost of composting is less than that of incineration. One uncertainty in all of the studies is the concentration of RDX and HMX adsorbed to the soil. It is likely that the portion of the contaminants contained in the soil matrix would undergo limited degradation.

\subsection{Chemical Treatment}

The use of a basic ion resin to treat RDX contaminated water was examined by Hoffsommer et al (1977). Degradation of RDX in the presence of the $\mathrm{OH}$ ion is shown in Equation 3.5. The amount of each product produced is dependent on the $\mathrm{OH}^{-}$concentration.

$$
\mathrm{C}_{3} \mathrm{H}_{6} \mathrm{~N}_{6} \mathrm{O}_{6}+\mathrm{OH}^{-} \rightarrow \mathrm{NO}_{2}^{-}+\mathrm{NH}_{3}+\mathrm{N}_{2} \mathrm{O}+\mathrm{N}_{2}+\mathrm{CH}_{2} \mathrm{O}+\mathrm{HCOO}
$$

Direct addition of lime or $\mathrm{NaOH}$ is not feasible. It would take $9.8 \mathrm{M} \mathrm{NaOH}$ to reduce the concentration of RDX from 45 to $4.5 \mathrm{ppm}$ in 20 minutes. Lime water with a $12 \mathrm{pH}$ would require 14 days to achieve the same reduction in $\mathrm{RDX}$ concentration. This decrease can be 
achieved much faster by the use of basic resin that adsorbs RDX and then chemically interacts with $\mathrm{OH}^{-}$ions on the resin.

The resin used was Amberlite 400 which had been converted from the chloride ion form to the hydroxide ion form with a $1 \mathrm{M} \mathrm{NaOH}$ solution. After the resin had been used it was regenerated by using a $1 \mathrm{M} \mathrm{NaCl}$ solution and then a $1 \mathrm{M} \mathrm{NaOH}$ solution.

In laboratory and pilot-scale, test water contaminated with $45 \mathrm{ppm}$ RDX was treated at a flow rate of 0.79 to $2.0 \mathrm{gpm}$ ( 0.067 to 0.17 resin volumes/minute). The concentration of the RDX in the effluent was less than $0.5 \mathrm{ppm}$. A resin volume of $1 \mathrm{ft}^{3}$ could be used to treat 1300 gallons of water contaminated with RDX at a concentration of $45 \mathrm{ppm}$. In both the laboratory and pilot-scale studies the resin was regenerated 8 times with no deterioration in performance. Hoffsommer, et al, (1977) concluded that a basic resin could be used for water contaminated with low levels of RDX which did not contain a large anion concentration. Also, it is likely HMX could be removed.

This process is somewhat limited by the low flow rate of the process. At an average flow rate of 0.12 resin volumes/minute, approximately 80 cubic feet of resin would be needed to treat 100,000 gallons of contaminated water in 24 hours at which time the resin must be regenerated. Therefore, this method could not be used to treat the 10 MGD of pink water generated at the Holston AAP (Burrows. 1982).

RDX and HMX can also be removed from water by coagulation (Sullivan, et al. 1979). The use of lime, ferric chloride, and Cat-Floc-T, a cationic polymer to remove HMX and RDX were studied. A $90 \%$ reduction in munition concentration was achieved using $500 \mathrm{mg} / \mathrm{l}$ of lime, and the initial RDX and HMX concentrations were not reported. The use of Cat-Floc-T is discouraged because it is not compatible with RDX in dry form. 


\section{Chapter 4}

\section{Conclusions}

The production and use of RDX and HMX in the US over the past 50 years has led to the contamination of soil and water at numerous sites. The concentration and extent of contamination is widely variable from site to site. The remediation of HMX and RDX is needed to reduce the threat they pose to human health and the environment.

The nature of these compounds in the environment poses several problems. Their low solubility and sorption onto soil is especially troublesome in treating ground waters. The low solubility of the compounds also limits their availability to microorganisms for biodegradation.

The most promising method of treating contaminated water appears to be the use of ultraviolet degradation in combination with ozone or hydrogen peroxide. Ultraviolet radiation provides a means of destroying the contaminants in an efficient and economical manner.

Composting has been well-studied as a means of treating contaminated soil and sediment. The concentrations of HMX and RDX in the environment can be rapidly degraded by the use of composting. However, studies should be conducted at the site to determine the optimum soil loading rate under specified conditions. 
The use of bioremediation for the treatment of waters and soils is a promising technology. The limiting factor in the use of bioremediation to treat contamination is the low solubility of the compounds. Much works needs to be done to see if bioremediation can be used in the field both in situ and ex situ. 


\section{References}

Binks, P. R., Nicklin S., and Bruce, N. C. (1995). "Degradation of hexahydro-1,3,5-trinitro1,3,5-triazine (RDX) by Stenotrophomonas maltophilia PB1." Appl. Envir. Microbiol., 61(4), 1318-1322.

Burrows, W. D. (1982) "Tertiary treatment of effluent from Holston AAP industrial liquid waste treatment facility. I. Batch carbon adsorption studies: TNT, RDX, HMX, TAX, and SEX." Technical Report 8207, ADA121244, US Army Armament Research and Development Command, NJ.

Burrows, W. D. (1983). "Tertiary treatment of effluent from Holston AAP industrial liquid waste treatment facility. III. Ultraviolet radiation and ozone studies: TNT, RDX, HMX, TAX, and SEX." Technical Report 8306, ADA137672, US Army Armament Research and Development Command, NJ.

Burrows, W. D., and Brueggemann, E. E. (1986). "Tertiary treatment of effluent from Holston AAP industrial liquid waste treatment facility. V. Degradation of nitramines in Holston AAP wastewaters by ultraviolet radiation." Technical Report 8602, ADA176195, US Army Toxic and Hazardous Materials Agency, Aberdeen Proving Ground, MD.

Dennis, R. M., Wujcik, W. J., Lowe, W. L., and Marks, P. J. (1990)). "Use of activated carbon for treatment of explosives-contaminated groundwater at the Milan Army Ammunition Plant (MAAP)." Report No. CETHA-TE-CR-90041, ADA235590, US Army Toxic and Hazardous Materials Agency, Aberdeen Proving Ground, MD.

Doyle, R. C., Isbister, J. D., Anspach, G. L., and Kitchens, J. F. (1986). “Composting organics/explosives contaminated soils." Report No. AMXTH-TE-CR-86077, ADA169994, US Army Toxic and Hazardous Materials Agency, Aberdeen Proving Ground, MD.

Doyle, R. C., and Kitchens, J. F. (1993). "Composting of soils/sediments and sludges containing toxic organics including high energy explosives." Contract No. 02112412, DE94004325, US Department of Energy, Washington, D.C.

Fernando, T., and Aust, S. D. (1990). "Biodegradation of munition waste, TNT (2,4,6trinitrotoluene), and RDX (hexahydro-1,3,5-trinitro-1,3,5-triazine) by Phanerochaete chrysosporium." Emerging Technologies in Hazardous Waste Management II, Tedder, D. W., and Pohland, F. G., eds., American Chemical Society, Washington, D.C., 214-232.

Fiala, E. S. (1977). "Investigations into the metabolism and mode of action of the colon carcinogens 1,2-dimethylhydrazine and azoxymethane." Cancer, 40(5), 2436-2445. 
Gibbs, T. R., and Popolato, A. (1980). LASL explosive property data. Los Alamos Scientific Laboratory. University of California Press, Berkeley.

Griest, W. H., Stewart, A. J., Tyndall, R. L., Ho, C. h-., and Tan, E. (1990). "Characterization of explosives processing waste decomposition due to composting." Report No, ORNL/TM11573, ADA224521 US Army Medical Research and Development Command, Fort Detrick, MD.

Hoffsommer, J. C., Kubose, D. A., and Glover, D. J. (1977). "Chemical degradation of RDX on strongly basic ion-exchange resins." Report No. NSWC/WOL/TR-77-30, ADA045230, Naval Surface Weapons Center, White Oak Laboratory, MD.

Isbister, J. D., Doyle, R. C., and Kitchens, J. F. (1982). "Engineering and development support of general decon technology of the U.S. Army's installation restoration program. Task II. Composting of explosives." Contract No. DAAK11-80-C-0027, ADA119276, US Army Toxic and Hazardous Materials Agency, Aberdeen Proving Ground, MD.

Kaplan, D. L. (1993). "Biotechnology and bioremediation for organic energetic compounds." Organic Energetic Compounds (In Press). P. Marinkas, eds., Nova Science Publishers, Inc., New York.

Kitchens, J. F., Harward, W. E., Lauter, D. M., Wentsel, R. S., and Valentine, R. S. (1978). "Preliminary problem definition study of 48 munitions related chemicals." Contract No. DAMD17-77-C-7057, ADA066307, US Army Research and Development Command, Fort Detrick, MD.

Kitts, C. L., Cunningham, D. P., and Unkefer, P. J. (1994). "Isolation of three hexahydro-1,3,5trinitro-1,3,5-triazine-degradaing species of the family Enterobacteriaceae from nitramine explosive-contaminated soil." Appl. Envir. Microbiol., 60(12), 4608-4711.

Knezovich, J. P., and Daniels, J. I. (1991). "Biodegradation of HE." Water Environ. Technol., $3(3), 34$.

Kobylinski, E. A., and Burrows, W. D. (1983). "Tertiary treatment of effluent from Holston AAP industrial waste treatment facility. II. Corona oxidation studies: TNT, RDX, HMX, TAX, and SEX." Technical Report 8215, ADA136877, US Army Medical Research and Development Command, Fort Detrick, MD.

Kubose, D. A., and Hoffsommer, J. C. (1977). "Photolysis of RDX in aqueous solution. Initial studies." Report No. NSWC/WOL/TR-77-20, ADA042199, Naval Surface Weapons Center, White Oak Laboratory, MD.

LaGrega, M. D., Buckingham, P. L., and Evans, J. C. (1994). Hazardous Waste Management. McGraw-Hill, Inc., New York, NY. 
McCormick, N. G., Cornell, J. H., and Kaplan, A. M. (1981). "Biodegradation of hexahydro1,3,5-trinitro-1,3,5-triazine." Appl. Envir. Microbiol., 42(5), 817-823.

McCormick, N. G., Cornell, J. H., and Kaplan, A. M. (1984). "The fate of hexahydro-1,3,5trinitro-1,3,5-triazine (RDX) and related compounds in anaerobic denitrifying continuous culture systems using simulated waste water." Technical Report Natick/TR-85/008, ADA149462. US Army Natick Research and Development Center, MA.

McLellan, W. L., Hartley, W. R., and Brower, M. E. (1988a). ). "Health advisory for hexahydro1,3,5-trinitro-1,3,5-triazine (RDX)." PB90-273533, US Army Medical Research and Development Command, Fort Detrick, MD.

McLellan, W. L., Hartley, W. R., and Brower, M. E. (1988b). "Health advisory for octahydro1,3,5,7-tetranitro-1,3,5,7-tetrazocine (HMX)." PB90-273525, US Army Medical Research and Development Command, Fort Detrick, MD.

Noss, C. I., and Chyrek, R. H., (1984). "Tertiary treatment of effluent from Holston AAP industrial liquid waste treatment facility. IV. Ultraviolet radiation and hydrogen peroxide studies: TNT, RDX, HMX, TAX, SEX." Technical Report 8308, ADA141135, US Army Medical Research and Development Command, Fort Detrick, MD.

Osmon, J. L., and Klausmeier, R. E., (1973). "The microbial degradation of explosives." Dev. Ind. Microbiol. 14, 247-252.

Regan, K. M., and Crawford, R. L. (1994). "Characterization of Clostridium bifermentans and it biotransformation of 2,4,6-trinitrotoluene (TNT) and 1,3,5-triaza-1,3,5trinitrocyclohexane (RDX)." Biotechnol. Lett., 16(10), 1081-1086.

Rosenblatt, D. H., Burrows, E. P., Mitchell, W. R., and Parmer, D. L. (1991). "Organic explosives and related compounds." The Handbook of Environmental Chemistry Vol. 3 Part G. O. Hutzinger, eds., Springer-Verlag, Berlin, 195-232.

Soli, G. (1973). "Microbial degradation of cyclonite (RDX)." NWC TP-5525, AD 762751. Naval Weapons Support Center, IN.

Spanggord, R. J., Mill, T., Chou, T. W., Mabey, W. R., Smith, J. H., and Lee, S., (1980). "Environmental fate studies on certain munition wastewater constituents. Final report, phase II-laboratory studies." Contract No. DAMMD17-78-C-8081, US Army Medical Research and Development Command, Fort Detrick, MD.

Spanggord, R. J., Mabey, W. R., Chou, T. W., Lee, S., Alferness, P. L., Tse, D. S., and Mill, T. (1983a). "Environmental fate studies of HMX. Phase II - detailed studies." Contract No. DAMD17-C-2100, US Army Medical Research and Development Command, Fort Detrick, MD. 
Spanggord, R. J., Mabey, W. R., Mill, T., Chou, T. W., Smith, J. H., Lee, S. and Robert, D. (1983b). "Environmental fate studies on certain munitions wastewater constituents. Phase IV-lagoon model studies." ADA138550, US Army Medical Research and Development Command, Fort Detrick, MD.

Sublette, K. L., Ganapathy, E. V., and Schwartz, S. (1992). "Degradation of munition wastes by Phanerochaete chrysosporium." Appl. Biochem. Biotechnol., 34/35, 709-723.

Sullivan, J. H., Putnam, H. D., Keirn, M. A., Pruitt, B. C., Nichols, J. C., and McClave, J. T. (1979). "A summary and evaluation of aquatic environmental data in relation to establishing water quality criteria for munitions-unique compounds. Part 4: RDX and HMX." ADA087683, US Army Medical Research and Development Command, Fort Detrick, MD.

Sweet, D. V. (1987). Registry of toxic effects of chemical substances. 1985-86 edition. National Institute for Occupational Safety and Health, Washington, D.C.

Thomas, J. M., and Ward, C. H. (1989). "In situ biorestoration of organic contaminants in the subsurface." Environ. Sci. and Technol., 23(7), 760-766.

Urbanski, T. (1963). Chemistry and technology of explosives. Vol. I. Pergamon Press Ltd, London.

U.S. Environmental Protection Agency. (1991). "Superfund record of decision: Bangor Naval Submarine Base, WA first remedial action." Report No. EPA/ROD/R10-91/033, PB92964603, U.S. Environmental Protection Agency, Washington, D.C.

U.S. Environmental Protection Agency. (1992). "Superfund record of decision: Savanna Army Depot, IL.” Report No. EPA/ROD/R05-92/200, PB93-964116, U.S. Environmental Protection Agency, Washington, D.C.

U.S. Environmental Protection Agency. (1993). "Selecting exposure routes and contaminants of concern by risk-based screening." Report No. EPA/903/R-93-001, Hazardous Waste Management Division, Office of Superfund Programs, Philadelphia, PA.

Williams, R. T., Ziegenfuss, P. S., and Sisk, W. E. (1992). "Composting of explosives and propellant contaminated soil under thermophilic and mesophilic conditions." J. Indust. Microbiol., 9, 137-144.

Yinon, J. (1990). Toxicity and metabolism of explosives. CRC Press, Ann Arbor, MI.

Yinon, J., and Zitrin, S. (1993). Modern methods and applications in analysis of explosives. Chichester, New York. 